\title{
Use of the Versatility of Fungal Metabolism to Meet Modern Demands for Healthy Aging, Functional Foods, and Sustainability
}

\author{
Jacqueline A. Takahashi ${ }^{1, *(D)}$, Bianca V. R. Barbosa ${ }^{1}$, Bruna de A. Martins $^{1} \mathbb{D}$, \\ Christiano P. Guirlanda ${ }^{2}$ and Marília A. F. Moura ${ }^{2}$ \\ 1 Department of Chemistry, Exact Sciences Institute, Universidade Federal de Minas Gerais, \\ Pres. Antônio Carlos Avenue, 6627, Pampulha, Belo Horizonte 31270-901, MG, Brazil; \\ biancavrb99@gmail.com (B.V.R.B.); bruna.almeidamartins@gmail.com (B.d.A.M.) \\ 2 Department of Food Science, Faculty of Pharmacy, Universidade Federal de Minas Gerais, \\ Pres. Antônio Carlos Avenue, 6627, Pampulha, Belo Horizonte 31270-901, MG, Brazil; \\ cpguirlanda@gmail.com (C.P.G.); mourafmari@gmail.com (M.A.F.M.) \\ * Correspondence: jat@qui.ufmg.br
}

Received: 31 August 2020; Accepted: 27 September 2020; Published: 15 October 2020

\begin{abstract}
Aging-associated, non-transmissible chronic diseases (NTCD) such as cancer, dyslipidemia, and neurodegenerative disorders have been challenged through several strategies including the consumption of healthy foods and the development of new drugs for existing diseases. Consumer health consciousness is guiding market trends toward the development of additives and nutraceutical products of natural origin. Fungi produce several metabolites with bioactivity against NTCD as well as pigments, dyes, antioxidants, polysaccharides, and enzymes that can be explored as substitutes for synthetic food additives. Research in this area has increased the yields of metabolites for industrial applications through improving fermentation conditions, application of metabolic engineering techniques, and fungal genetic manipulation. Several modern hyphenated techniques have impressively increased the rate of research in this area, enabling the analysis of a large number of species and fermentative conditions. This review thus focuses on summarizing the nutritional, pharmacological, and economic importance of fungi and their metabolites resulting from applications in the aforementioned areas, examples of modern techniques for optimizing the production of fungi and their metabolites, and methodologies for the identification and analysis of these compounds.
\end{abstract}

Keywords: fungi; secondary metabolites; metabolomics; NTCD; additives; functional foods; nutraceuticals; sustainability; healthy aging

\section{Health and Modern Food Demands}

Health concerns have always existed among humans. Although some conditions and diseases cannot be avoided yet, the manifestation of several non-transmissible chronic diseases (NTCD) with high prevalence in patients over 60 years of age such as diabetes, cardiovascular, and neurodegenerative diseases can be delayed by adhering to a healthy lifestyle, which among other factors, is directly correlated to eating habits. The physiological effects associated with the consumption of certain foods are thus becoming very popular. Several types of diets and foods such as the fat-free diet, low-carb diet [1], Mediterranean diet [2], and soy-based diet [3] have been adopted in the quest for healthy aging. Several effects of NTCD have also been postponed through calorie restriction diets in animal models [4]. However, prolonged caloric restriction in humans generates undesirable effects; thus, alternative ways of preventing NTCD have been sought through the development of drugs, foods, and/or nutraceuticals that have both health-promoting and anti-aging effects, without causing adverse effects [5]. There is an 
increasing trend to combine the use of nutraceuticals with pharmacotherapy, even among individuals with non-aging-related diseases.

As oxidative stress is among the metabolic factors and pathways most related to cell aging, the consumption of nutraceuticals and functional foods with antioxidant activity has increased. Antioxidants can benefit the human body by directly or indirectly neutralizing reactive oxygen species (ROS), modulating metabolic pathways and gene expression, and activating mechanisms of cellular stress and autophagy that delay aging through pathways unrelated to ROS [5]. The nutraceutical market has already reached market values up to USD 117 billion [6]. Nutraceuticals can be classified into several categories based on the level of innovation and area of application (Table 1) [7,8]. Another trend associated with health improvement and NTCD prevention is that of consuming natural foods or foods containing natural, rather than synthetic, additives such as natural flavoring agents, acidulants, and colorants. Several people also prefer vegetarian and vegan diets, which involve restrictions in food and additives of animal origin to different extents; such diets are mainly motivated by the environmental impacts of livestock farming and animal welfare and have prompted studies on the possible effects of these diets on health [9] and increased the market demand for new vegetarian and vegan food products.

Filamentous fungi are capable of responding to different demands for the development of functional foods, nutraceuticals, and bioactive substances that can be used as medicines or in the food industry, either through the use of their biomass or the metabolites produced by them. A comprehensive review of the various aspects of fungal biotechnology and industrial applications was recently published by Meyer et al. [10].

The consumption of fungi as food mainly involves the consumption of mushrooms (Ascomycota and Basidiomycota phyla), which are enjoyed worldwide, sometimes as delicatessen or gourmet products. However, the role of fungi in human and animal health extends much further than the recognized health benefits of mushrooms [11]. Many fungal species are commercially available as supplements or nutraceuticals, and the fungal metabolites produced by these organisms including many non-Basidiomycota species as functional foods have multiple pharmacological activities. Examples of fungal species used as functional foods include many species of microscopic filamentous fungi that are easily cultivated under ex situ scalable conditions such as some well-known Penicillium, Aspergillus, and Fusarium species. However, lesser known species such as Ashbya gossypii also play an important role in the production of food additives such as riboflavin (vitamin B2) (1) (Figure 1) [12]. Other important fungal products associated with health improvement are enzymes such as $\beta$-galactosidase, which hydrolyzes lactose from dairy foods, is produced by filamentous fungi such as Trichoderma sp., and is helpful for lactose-intolerant individuals [13].

Table 1. Examples of food additives and nutraceuticals from fungi.

\begin{tabular}{|c|c|c|c|c|}
\hline Category & Active Component & Bioactivity & Fungal Source & References \\
\hline Nutrient & Vitamin C (55) & Antioxidant & Dictyophora indusiata & [14] \\
\hline \multirow{2}{*}{ Secondary Metabolites } & Resveratrol & Antioxidant & Pleurotusostreatus & [15] \\
\hline & Agmatine (28) & Neurological benefits & Aspergillus oryzae & [16] \\
\hline $\begin{array}{c}\omega-6 \\
\text { Polyunsaturated fatty acid }\end{array}$ & Arachidonic acid & $\begin{array}{l}\text { Development of the nervous central system } \\
\text { and enhancement of immune response }\end{array}$ & Mortierella alpina & [18] \\
\hline Probiotic & Whole cell & $\begin{array}{l}\text { Increase of beneficial bacteria population in } \\
\text { gastrointestinal tract }\end{array}$ & Saccharomyces boulardii & [19] \\
\hline Nutraceutical Enzymes & Lipase (Lipopan F) & Decrease glycemic response & Rhizopus oryzae & [22] \\
\hline Fortified Nutraceuticals & $\begin{array}{l}\text { Folate in fermented } \\
\text { maize-based porridge }\end{array}$ & & Saccharomyces cerevisiae & [23] \\
\hline
\end{tabular}

This review discusses the usefulness of metabolites produced by fungi for food and pharmaceutical purposes closely linked to health improvement and the prevention of NTCD, respectively, as lead compounds, additives, nutraceuticals, supplements, and functional ingredients. The health benefits of fungal metabolites are highlighted. Cutting-edge tools for yield improvement and thus the scaling up 
of fungal metabolite production as well as the means for ensuring a successful circular economy in this area are also discussed.

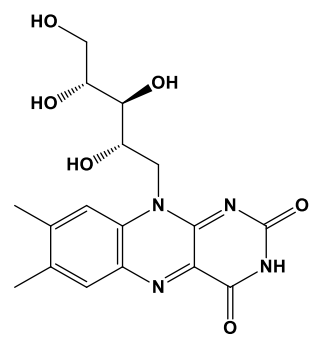

(1)

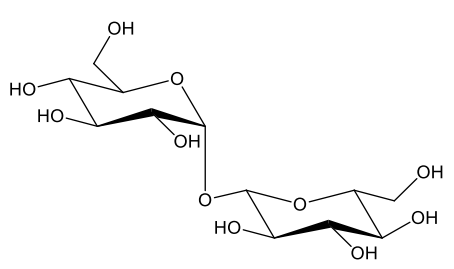

(51)

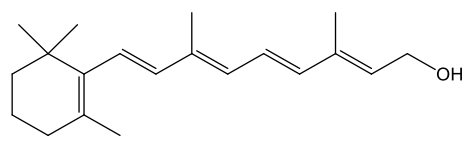

(54)

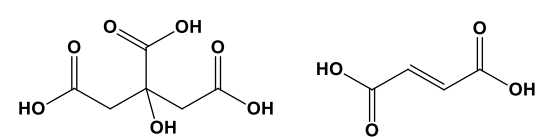

(2) (3)<smiles>O=C(O)[C@H](O)[C@H](O)[C@H](O)[C@H](O)CO</smiles>

(4)<smiles>O=C(O)CC(O)C(=O)O</smiles>

(22)
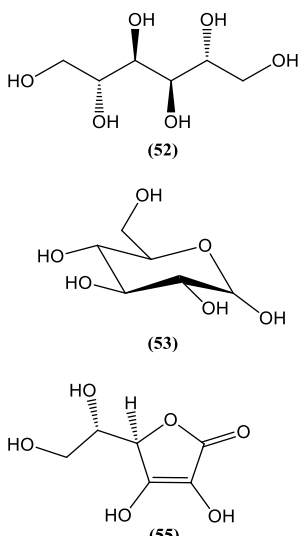

(55)

Figure 1. Chemical structures of some fungal-derived food additives (1-4, 22, 51-55).

\section{Natural Food Additives from Fungi}

Prompted by the growing evidence for the association between natural compound intake and health, there is a demand for the replacement of synthetic food additives with natural products. Fungal metabolites feature many properties that have been explored for such replacement. This section presents the potential of fungal metabolites as food additives, focusing on their versatility as coloring agents, producing species, and recent achievements and challenges in this area.

Fungi provide several food additives and technology adjuvants such as organic acids, colorants, and fatty acids including some $\omega-3$ and $\omega-6$ class fatty acids, which are essential for human metabolism. Citric acid (2) and fumaric acid (3) (Figure 1), metabolites of Aspergillus niger and Rhizopus oryzae, respectively, are outstanding food additives that are industrially produced. Citric acid (2) and gluconic acid (4) (Figure 1) are fungal products with the highest commercial-scale production [24]. Citric acid (2) has a number of applications as an antioxidant, preservative, acidulant, $\mathrm{pH}$ control agent, and flavor regulation agent, with market numbers predicted to reach USD 3.6 billion in 2020 [24].

The harmful effects of synthetic food colorants on human health such as attentiondeficit/hyperactivity disorder, asthma and allergies, cancer, and neurological disorders have accelerated the search for natural substitutes. The use of the yellow coloring compounds tartrazine, quinoline, and sunset as well as the red coloring compound amaranth [25] has been regulated and supervised by the World Health Organization. In addition, sustainability issues have contributed to the decreased acceptability of non-biodegradable synthetic colorants that are difficult to remove from effluents, causing toxic effects on plants, bacteria, algae, fishes, and crustaceans [26]. Fungal pigments and dyes have emerged as alternatives to these synthetic food additives [27].

Food dyes are coloring materials soluble in food substrates, while food pigments are insoluble in food and need to be carried by vehicles that bind to the food instead [28] (ACS, 2020). Food colorants are pigments or dyes approved for use as food additives [29] (FDA, 2017). A wide spectrum of natural colors can be obtained from metabolites of fungi of different genera such as Eurotium, Fusarium, 
Monascus, and Penicillium, isolated from marine and terrestrial environments and extracted by techniques considered environmentally friendly including those employing ultrasound, pressurized liquid, microwaves, and pulsed electric field [30]. The fungal metabolites have a wide color range, which can be represented by carotenoids such as lycopene (red) (5), $\beta$-carotene (yellow-orange) (6), and astaxanthin (pink-red) (7); azafilones such as monascorubrin (orange) (8) and ankaflavin (yellow) (9); and the quinine derivatives alizarin (purple-red) (10) and bikaverin (red) (11) (Figure 2). Arpink Red (12) (Figure 2), an anthraquinone produced by Penicillium oxalicum, has been approved by the Codex Alimentarius for use as a food colorant in meat products, dairy, confectionery, ice cream, and alcoholic and non-alcoholic beverages [31,32]. Naftoquinone hydrosoluble metabolites (purple color) were produced by a soil-originated strain of Fusarium oxysporum using a simple culture medium containing glucose, ammonium sulfate, and salts [33]. Crystalline neoechinulin A (13) (ivory color), neoechinulin B (14), and cladosporin (15) (all having a yellow color) (Figure 2) are described as metabolites of Eurotium amstelodami, Eurotium herbariorum, and Eurotium rubrum isolated from outdoor and indoor samples in Canada and grown in medium containing sucrose, yeast extract, and salts [34].

The filamentous fungus Monascus purpureus is one of the first species that was used to produce natural colorants. It is traditionally consumed in Asia in fermented red rice, which is important in Chinese cuisine, and used in folk medicine as a regulator of digestive and circulatory functions [35,36]. Some species of the genus Monascus produce the secondary metabolite monacolin K (16) (Figure 2), which consists of a lactone with a free hydroxyl-acid moiety. Aside fromits coloring property, monacolin K (16) has a high antioxidant activity and is marketed as a hypocholesterolemic drug known as lovastatin. The pigments of yellow, orange, and red color produced by the Monascus genus are considered safe for human consumption [37].

The development of mutant strains of Monascus has enabled an increase in available pigments including monashin (17) (Figure 2), which is obtained through the mutation of the enzyme polyketide synthase and has an antioxidant activity [35]. The monascin (18) (Figure 2) (yellow) produced by M. purpureus after activation by the transcription factors DAF-16/FOXO increased the production of superoxide dismutase and thermal shock protein HSP16.2, improving survival in a worm model [38]. Monascin (18) also reduced non-alcoholic fatty liver disease and increased AMPK levels and $\gamma 1 \alpha$ co-activator of the receptor activated by peroxisome proliferator in mice [39]. In another study, a new azaphylone, monapurpureusone (19), and a new brownish natural product, monapurpureusin (20) (Figure 2), were obtained from a mutant strain of $M$. purpureus cultivated in fermented rice extract. Both compounds presented superoxide radical scavenging activity $\left(\mathrm{EC}_{50}=176.2\right.$ and $271.2 \mu \mathrm{M}$, respectively), with monapurpureusone (19) superior to the control gallic acid $(237.1 \mu \mathrm{M})$, and anti-inflammatory activity ( $\mathrm{IC}_{50}=27.5$ and $24.9 \mu \mathrm{M}$, respectively), with both compounds superior to the control quercetin $(35.9 \mu \mathrm{M})$ [36].

Red and orange pigments were produced by a strain of Talaromyces albobiverticillius isolated from a marine environment at $\mathrm{pH} 6.5$, and their colors were shown to be dependent on the fermentation period (198.6 and 229.0 h, respectively) [40]. Optimal conditions for the production of pigments were also described for F. oxysporum (red color, rate $\mathrm{C}: \mathrm{N}=9$, blue LED light, and absence of co-culture) and Aspergillus chevalieri (yellow color, rate $\mathrm{C}: \mathrm{N}=20$, glucose as the carbon source, UV and red light, and co-cultivation with Kluyveromyces marxianus) [41]. The production of natural food colorants such as melanins, azaphilones, flavins, phenazines, and quinines by filamentous fungi has also been reported for Basidiomycetes [28].

The replacement of synthetic colorants with fungal pigments and dyes enables the production of safer and healthier foods. Compared with plant sources of natural pigments, fungal sources are more economically attractive, considering the relative ease of yield maximization by manipulating fungal fermentative parameters instead of relying on seasonal factors, as may occur in the production of pigments and dyes of plant origin. 


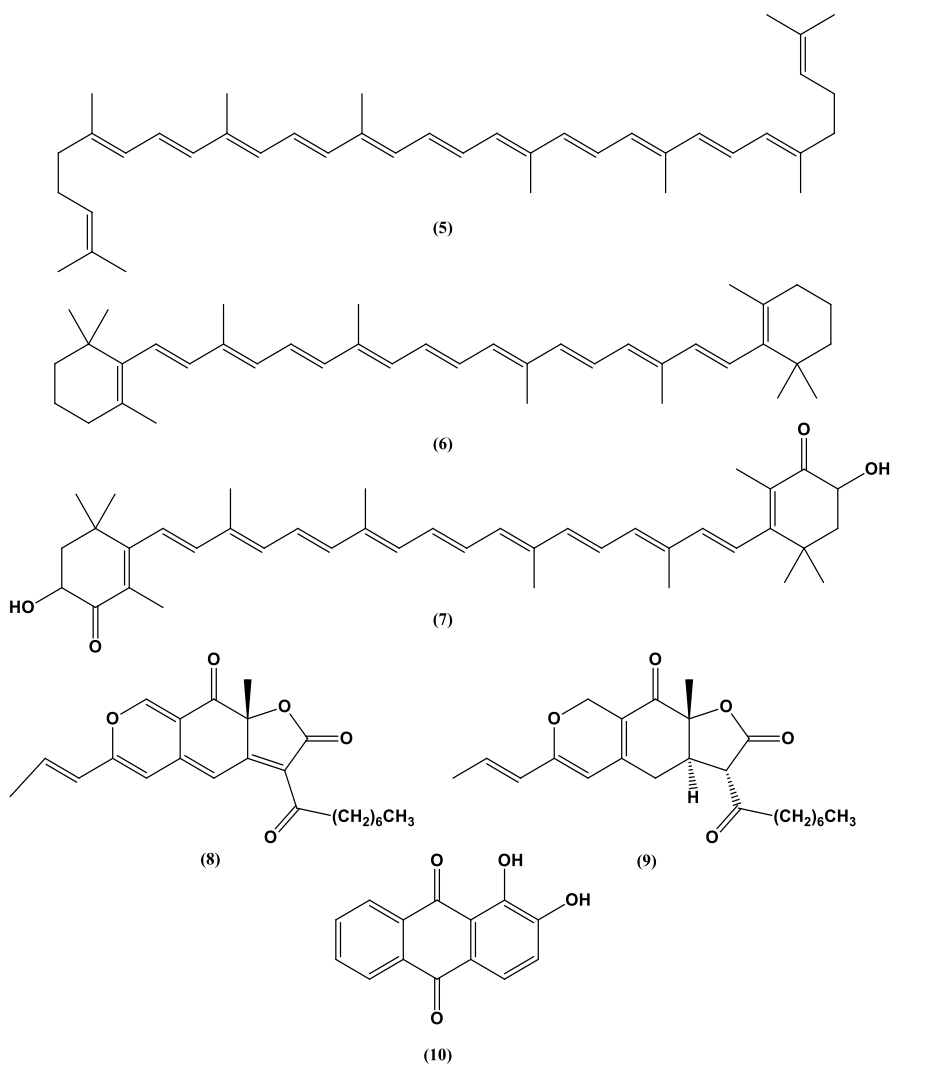

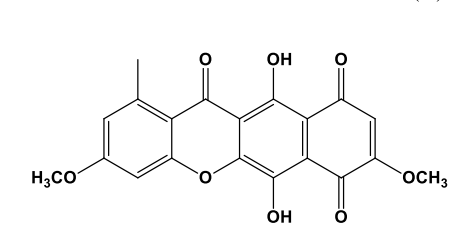

(11)
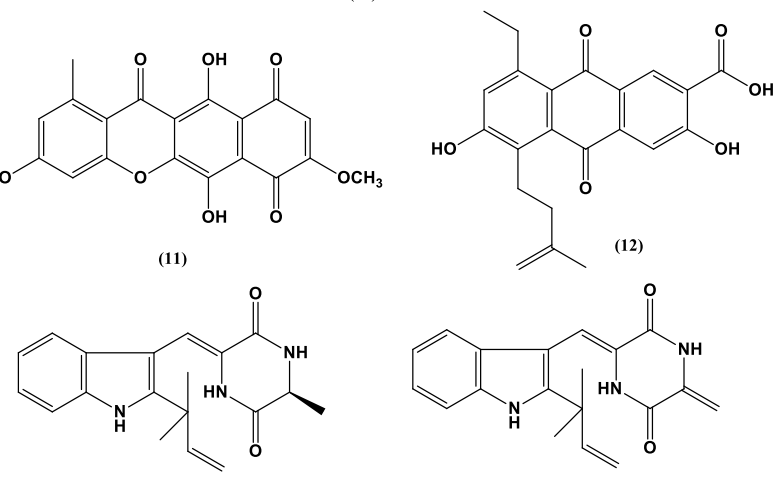

(13)

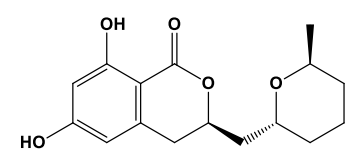

(15)
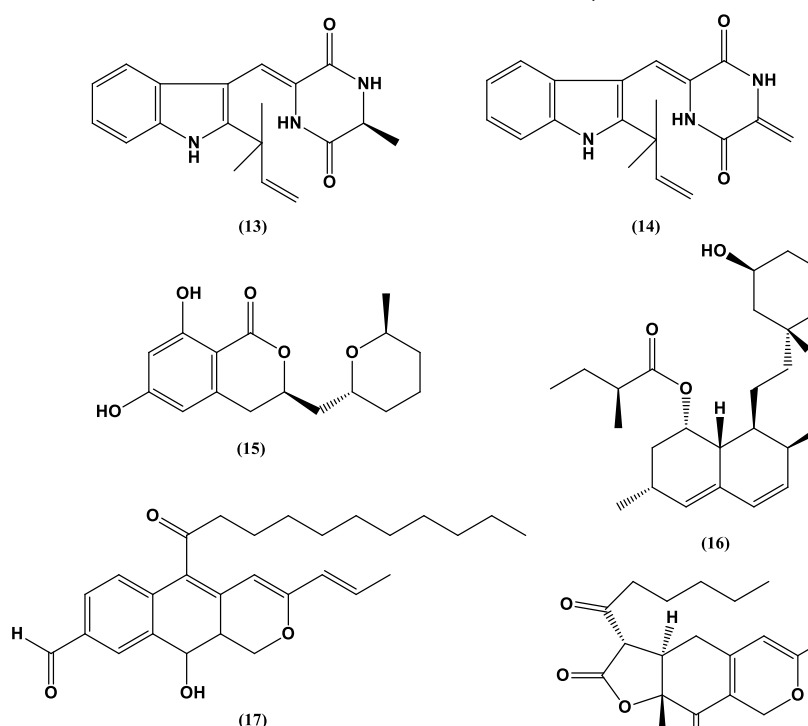

(14)

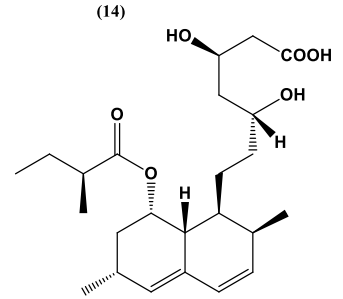

(16)

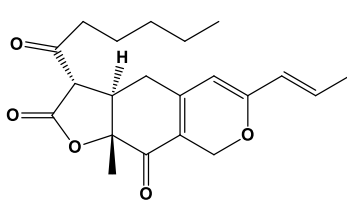

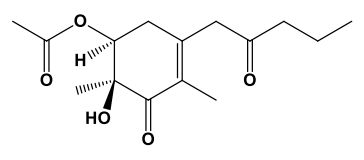

(19)
(18)

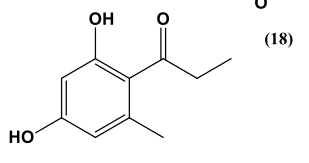

(20)

Figure 2. Chemical structures of some colored fungal secondary metabolites (5-20). 
Nevertheless, some challenges need to be considered for regulating new food-related colorants such as the possibility of interactions with the food matrix, which causes undesirable sensorial changes, loss of color stability, and contamination by toxic substances such as mycotoxins. Some alternatives proposed for these problems are based on the controlled release of the colorant using microencapsulation as well as the use of nanoformulations to eliminate undesirable aromas and flavors [30]. Spray-drying microencapsulation was successfully used in broth fermented by three species producing yellow dyes, Aspergillus keveii, Penicillium flavigenum, and Epicoccum nigrum. Encapsulation with three adjuvants (maltodextrin, modified starch, and gumarabic) provided pigment retention above 70\% [41]. With respect to problems linked to the production of mycotoxins such as citrinin (21) (Figure 3) produced by Monascus, strategies vary from changes in cultivation and fermentation conditions to disruption of genes encoding the production of mycotoxins in question to create non-mycotoxin-producing mutant strains [30].<smiles>CC1=C2C(=CO[C@@H](C)[C@@H]2C)C(O)=C(C(=O)O)C1=O</smiles>

(21)<smiles>CO[C@H](C)CCCC(=O)CCC/C=C/c1cc(O)cc(O)c1C(=O)O</smiles>

(29)

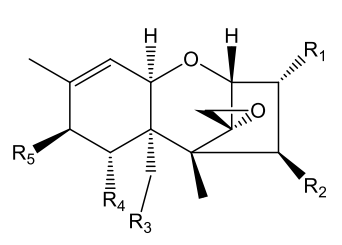

(30)<smiles>[R]C(CCCCC([R8])CC(O)C(C)N)CC(C)CC(OC(=O)CC(CC(=O)O)C(=O)O)C(OC(=O)CC(CC(=O)O)C(=O)O)C(C)CCCC</smiles>

Figure 3. Chemical structures of some mycotoxins $(\mathbf{2 1}, \mathbf{2 9 )}$ and classes of mycotoxins $(\mathbf{3 0}, \mathbf{3 1})$ frequently produced by fungal species.

The use of fungal metabolites as natural colorants contributes greatly to the development of healthier foods. Nonetheless, several other additives of fungal origin such as substances related to taste and $\mathrm{pH}$ (acidulants, flavorings, and sweeteners), texture (thickeners and emulsifiers), and increased shelf life (antioxidants and preservatives) have been studied. Some examples can be found in Table 2. The application of some of these additives including exopolysaccharides is not restricted to the food industry. Fungal exopolysaccharides produced by species such as Phellinus linteus, Ganoderma lucidum, Fusarium sp., Pleurotus spp., Inonotus obliquus, and Aureobasidium pullulans have been employed to aid moisture retention in confectionery, increase the viscosity and crystallization of sugar, and as stabilizers, emulsifiers, and thickening agents [42,43]. These compounds are also of great interest to textiles, food, cosmetics, and pharmaceutical industries and are also important in agriculture as preservatives, bioherbicides, and microbicides. 
Table 2. Examples of non-coloring natural additives from fungal origin.

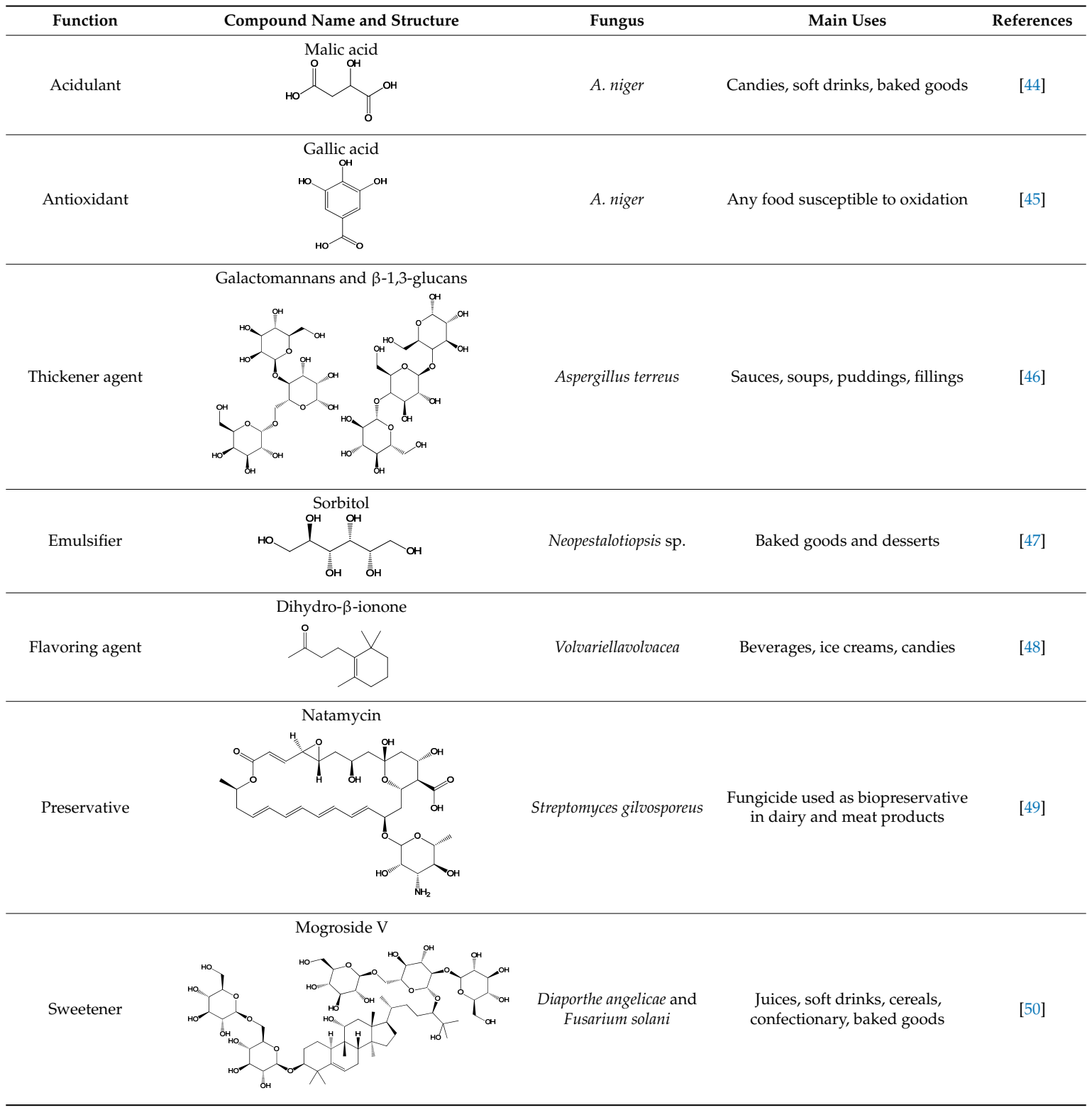

Metabolic engineering of microorganisms has been successfully employed for producing 42 out of the 316 food additives from numerous species of fungi and bacteria currently approved by the European Union [44]. Using this technique, the production of glutamic acid, a metabolite capable of providing "umami" flavor to food, though fermentation with Corynebacterium glutamicum was optimized. The production of malic acid (22) (Figure 1), an acidulant used in food and beverages, was increased after overexpression of the genes encoding its precursors in the species S. cerevisiae, Aspergillus flavus, Aspergillus oryzae, and A. niger [51,52]. Metabolic engineering can also be used to introduce heterologous routes for enzyme production in microorganisms (e.g., to produce enzymes of plant origin) [51]. Changes in the molecular structures and colors of microbial pigments were made using the engineering system CRISPR-Cas9, which cleaves specific microbial DNA sites and introduces changes in one or more target genes [30]. For instance, Escherichia coli was used for the production of $\beta$-carotene (6) through genomic editing to introduce insertions, deletions, and substitutions in regions of the lacZ, galK, and ldhA genes using the CRISPR-Cas9 system [53].

A yeast species, Yarrowia lipolytica, was engineered by introducing genes for the production of $\beta$-ketolase and $\beta$-hydroxylase of seaweed and bacteria origin, increasing the yield of astaxanthin 
(7) $(285 \pm 19 \mathrm{mg} / \mathrm{L} ; 47 \%$ of total carotenoids) [54]. This was a great achievement, given the lower productivity of astaxanthin (7) by yeasts like Xanthophyllomyces dendrorhous (10.2 $\mathrm{mg} / \mathrm{L})$ [55] and microalgae like Haematococcus pluvialis $(84.8 \mathrm{mg} / \mathrm{L})$ [56] and Chlorella zofingiensis (12.5 mg/L) [57]. Astaxanthin (7) has a high market value (USD 2500-7000/kg), 5-20 times higher than that of $\beta$-carotene (6) produced by the microalga Dunaliella salina (USD 300-500/kg) [54,58].

Overall, tools such as genetic manipulation based on transcriptomic analysis, induction of mutations, cloning, and insertion of heterologous plasmids into species with well-known genomes have enabled the production of large quantities of metabolites by previously non-producing species [59]. The elucidation and manipulation of the different stages in the transcription and secretion of amylases, xylanases, and cellulases in filamentous fungi has enabled their overexpression [60]; these enzymes are widely used in bakery products to improve the quality of dough through hydrolysis of long-chain carbohydrates and non-starch polysaccharides (cellulose and arabinoxylans).

It was hypothesized that enzymes produced by $A$. oryzae and A. niger could cleave the anti-nutritional factors present in flour, in addition to hydrolyzing proteins and carbohydrates into smaller molecules and thus making them more accessible for digestion and releasing phenolic compounds from the matrix. However, the fungi used the amino acids present in the flour for their own metabolism, which negatively affected the protein quality of the final product [61]. A new fermented food product was thus developed using stale bread as a substrate for the fungus Neurospora intermedia, which converted $65 \%$ of the starch into $21 \%$ of protein, in addition to supplementing the final product with minerals and vitamins; although there was a reduction in the amounts of proline, glutamic acid, and phenylalanine, the overall amino acid composition was improved [62].

\section{Benefits, Research, and Industrial Applications of Fungal Metabolites}

The scope of the pharmacological activity of fungal metabolites seems to be as endless as the structural diversity. However, several issues in this area must be addressed such as the extent of in vivo effects. The wide range of beneficial biological effects of fungal metabolites can be related to the prevention and treatment of NTCD, and some such effects have identified several potential compounds for developing new drugs.

Terrein (23) (Figure 4), for instance, is a secondary metabolite biosynthesized in high concentrations $(537.26 \pm 23.42 \mathrm{~g} / \mathrm{kg}$ crude extract) by A.terreus [63]. The anti-inflammatory and antioxidant properties of terrein (23) were reported in in vitro studies [64]. These important medicinal properties and the high initial yield of this metabolite allow the large-scale production and technological development of the A. terreus crude extract for the prevention of some age-related NTCD.

Compounds presenting cytotoxicity against tumor cells form one of the most important classes of fungal metabolites. The world incidence of cancers is high, with cancer affecting one in five people at some point in life. The number of cancer cases registered in 2018 was 18.1 million people, a number that could double in 2040 [65]. Cancer is a multifactorial disease that affects people regardless of age, gender, or origin. As an NTCD, cancer is worrying in several ways, since working-age people can be affected, treatment is costly and long, mortality rates are high, and individuals often have health issues even after cure.

Many reports on fungal metabolites with cytotoxic activity show the vast arsenal of molecules that fungi provide to combat cancer. Table 3 provides examples of antitumor metabolites produced by fungi. Species from different genera or secondary metabolites produced by them sometimes present inhibitory power more pronounced than or relatively close to that presented by standard compounds. This was observed for hypocriol A (24) and F (25) (Figure 4), isolated from the strain Hypocrea sp. [66], and for sesquiterpene strichocaranes E (26) and F (27) (Figure 4), isolated from the entomopathogenic fungus Isaria fumosorosea [67], in comparison to the standard cisplatin. Many human tumor cell lines can be inhibited by fungal metabolites such as breast (MDA and MCF-7) [67], cervical and lung [66], colorectal [63], gastric and liver [68], and pancreatic [69] cell lines. The majority of compounds 
presented in Figure 4 are terpenes with different degrees of hydroxylation as well as linear and cyclic nitrogen-bearing compounds with free $\mathrm{NH}$ groups.

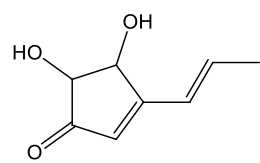

(23)
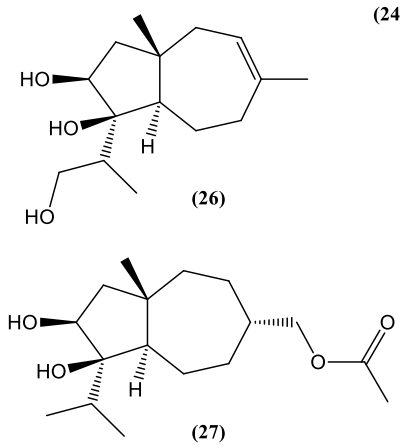

(27)<smiles>NCCCCN=C(N)N</smiles>

(24)
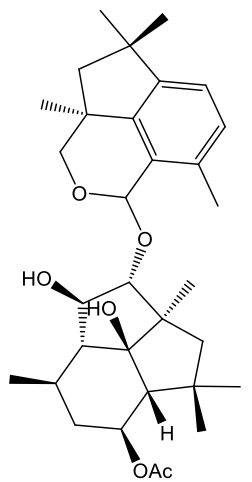

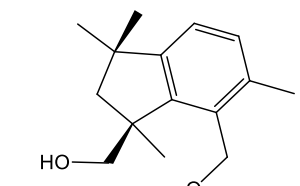

(25)

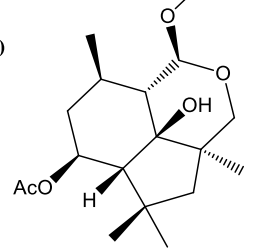<smiles>[R20]c1cc(O)c2c(c1[R16])C(=O)c1cc(C)ncc1C2=O</smiles>

(32) $\mathrm{R}_{1}=\mathrm{OCH}_{3}, \mathrm{R}_{2}=\mathrm{H}, \mathrm{R}_{3}=\mathrm{H}$

(33) $\mathrm{R}_{1}=\mathrm{H}, \mathrm{R}_{2}=\mathrm{H}, \mathrm{R}_{3}=\mathrm{CH}_{3}$

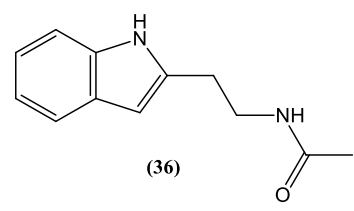

(35)<smiles>C=C(/C=C/C(CCC(C)=O)C(C)(C)O)CCC(=O)O</smiles>

(38)

(37)<smiles>C=C1C=C[C@H](C)[C@H](CC[C@H]2C[C@@H](O)CC(=O)O2)[C@H]1C</smiles>

(40)

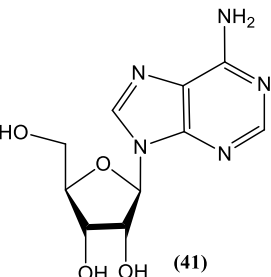

Figure 4. Cont. 

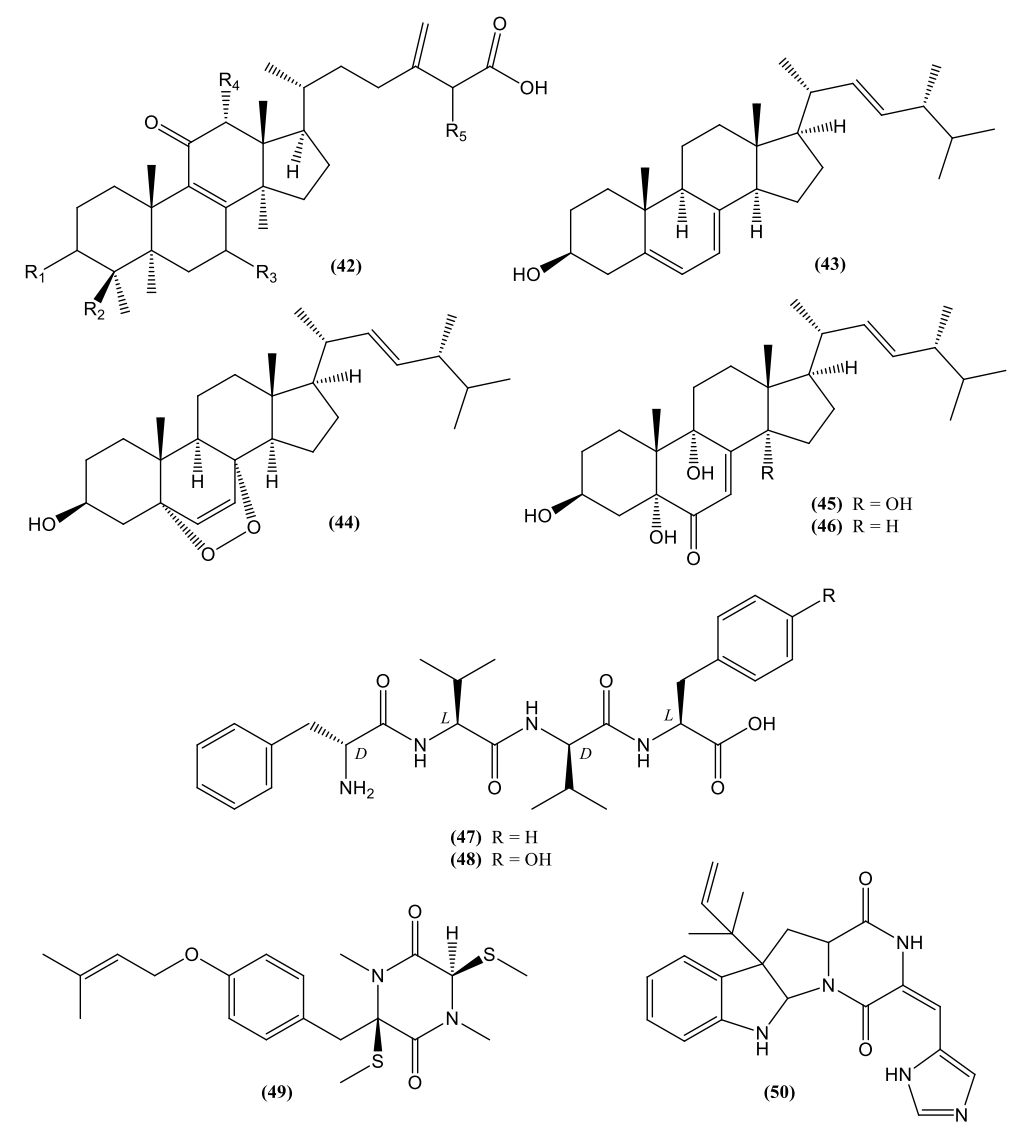

Figure 4. Chemical structures of metabolites (23-28, 32-41, 43-50) and class of bioactive compounds (42) produced by fungal species. 
Table 3. Cytotoxic activity of some fungal secondary metabolites against several human tumor cell lines.

\begin{tabular}{|c|c|c|c|c|c|c|c|}
\hline \multirow{2}{*}{ Metabolite } & \multirow{2}{*}{ Fungal Origin } & \multirow{2}{*}{ Yield } & \multicolumn{4}{|c|}{ Cytotoxic Activity } & \multirow{2}{*}{ Reference } \\
\hline & & & Human Tumor Cell & $\mathrm{IC}_{50}$ & Control & $\mathrm{IC}_{50}$ & \\
\hline \multirow{5}{*}{ 7-Desmethyl-6-methylbostrycoidin (32) } & \multirow{5}{*}{ F. solani } & \multirow{5}{*}{$7 \mathrm{mg} / 4.3 \mathrm{~g}$ extract } & Breast (MDA MB 231) & $0.73 \mu \mathrm{M}$ & \multirow{5}{*}{ Doxorubicin } & $0.07 \mu \mathrm{M}$ & \multirow{5}{*}{ [69] } \\
\hline & & & Pancreatic (MIA PaCa2) & $0.64 \mu \mathrm{M}$ & & $0.04 \mu \mathrm{M}$ & \\
\hline & & & Cervical (HeLa) & $0.71 \mu \mathrm{M}$ & & $0.05 \mu \mathrm{M}$ & \\
\hline & & & Non small-cell lung (NCI HI975) & $0.34 \mu \mathrm{M}$ & & $0.03 \mu \mathrm{M}$ & \\
\hline & & & Lung fibroblast (WI38) & $6.42 \mu \mathrm{M}$ & & $0.35 \mu \mathrm{M}$ & \\
\hline \multirow{5}{*}{ 7-Desmethylscorpinone (33) } & \multirow{5}{*}{ F. solani } & \multirow{5}{*}{$5 \mathrm{mg} / 4.3 \mathrm{~g}$ extract } & Breast (MDA MB 231) & $1.51 \mu \mathrm{M}$ & \multirow{5}{*}{ Doxorubicin } & $0.07 \mu \mathrm{M}$ & \multirow{5}{*}{ [69] } \\
\hline & & & Pancreatic (MIA PaCa2) & $0.98 \mu \mathrm{M}$ & & $0.04 \mu \mathrm{M}$ & \\
\hline & & & Cervical (HeLa) & $0.96 \mu \mathrm{M}$ & & $0.05 \mu \mathrm{M}$ & \\
\hline & & & Non small-cell lung (NCI HI975) & $0.61 \mu \mathrm{M}$ & & $0.03 \mu \mathrm{M}$ & \\
\hline & & & Lung fibroblast (WI38) & $5.84 \mu \mathrm{M}$ & & $0.35 \mu \mathrm{M}$ & \\
\hline \multirow{2}{*}{ Ergosterol (43) } & Penicillium chrysogenum & ni & Breast (MCF-7) & $0.10 \mathrm{mM}$ & ni & ni & [70] \\
\hline & V.volvacea & $500 \mathrm{mg} / 725 \mathrm{~g}$ extract & Prostate (PC-3M) & $27.98 \pm 0.97 \mu \mathrm{M}$ & 5-Fluorouracil & $64.35 \mu \mathrm{M}$ & [68] \\
\hline Ergosterol peroxide (44) & V. volvacea & $15 \mathrm{mg} / 725 \mathrm{~g}$ extract & Prostate (PC-3M) & $23.15 \pm 1.54 \mu \mathrm{M}$ & 5-Fluorouracil & $64.35 \mu \mathrm{M}$ & [68] \\
\hline $3 \beta, 5 \alpha, 9 \alpha, 14 \alpha$-Tetrahydroxy-ergosta-7,22-dien-6-one (45) & V. volvacea & $5.9 \mathrm{mg} / 725 \mathrm{~g}$ extract & Liver (HepG2) & $20.72 \pm 0.76 \mu \mathrm{M}$ & 5-Fluorouracil & $54.74 \mu \mathrm{M}$ & [68] \\
\hline \multirow{2}{*}{$3 \beta, 5 \alpha, 9 \alpha-$-Trihydroxy-ergosta-7,22-dien-6-one (46) } & \multirow{2}{*}{ V. volvacea } & \multirow{2}{*}{$12.5 \mathrm{mg} / 725 \mathrm{~g}$ extract } & $\begin{array}{l}\text { Gastric (SGC-7901) } \\
\end{array}$ & $12.03 \pm 0.77 \mu \mathrm{M}$ & \multirow{2}{*}{ 5-Fluorouracil } & $75.05 \mu \mathrm{M}$ & \multirow{2}{*}{ [68] } \\
\hline & & & Liver (HepG2) & $5.90 \pm 0.44 \mu \mathrm{M}$ & & $54.74 \mu \mathrm{M}$ & \\
\hline \multirow{4}{*}{ Hypocriol A (24) } & \multirow{4}{*}{ Hypocrea sp. } & \multirow{4}{*}{$50.3 \mathrm{mg} / 63.2 \mathrm{~g}$ extract } & Colorectal (HCT116) & $18.6 \pm 0.7 \mu \mathrm{M}$ & \multirow{4}{*}{ Cisplatin } & $18.8 \pm 1.9 \mu \mathrm{M}$ & \\
\hline & & & Cervical (HeLa) & $7.7 \pm 0.4 \mu \mathrm{M}$ & & $14.7 \pm 0.8 \mu \mathrm{M}$ & {$[66]$} \\
\hline & & & Lung (A549) & $25.3 \pm 2.5 \mu \mathrm{M}$ & & $13.8 \pm 1.2 \mu \mathrm{M}$ & {$[00]$} \\
\hline & & & Breast (MCF-7) & $19.7 \pm 0.4 \mu \mathrm{M}$ & & $17.6 \pm 2.4 \mu \mathrm{M}$ & \\
\hline & & & Colorectal (HCT116) & $2.7 \pm 0.6 \mu \mathrm{M}$ & & $18.8 \pm 1.9 \mu \mathrm{M}$ & \\
\hline Hypocriol F (25) & Hupocrea $\mathrm{sp}$. & $11.2 \mathrm{mg} / 63.2 \mathrm{~g}$ extract & Cervical (HeLa) & $4.6 \pm 0.1 \mu \mathrm{M}$ & Cisplatin & $14.7 \pm 0.8 \mu \mathrm{M}$ & {$[66]$} \\
\hline 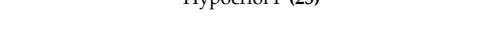 & . & 11.2 Higlos.2 gextrate & Lung (A549) & $15.3 \pm 1.6 \mu \mathrm{M}$ & Aspiatiti & $13.8 \pm 1.2 \mu \mathrm{M}$ & {$[000$} \\
\hline & & & Breast (MCF-7) & $23.6 \pm 1.3 \mu \mathrm{M}$ & & $17.6 \pm 2.4 \mu \mathrm{M}$ & \\
\hline & & $537.26 \pm 23.42 \mathrm{~g} / \mathrm{kg}$ extract & Colorectal (HCT-116) & $12.13 \mu \mathrm{M}$ & Doxorubicin & $0.11 \mu \mathrm{M}$ & [63] \\
\hline Ierrein (23) & A. terreus & $307.20 \pm 20.42 \mathrm{~g}$ g k gextract & Hepatocellular (HepG2) & $22.53 \mu \mathrm{M}$ & Doxorubicin & $0.85 \mu \mathrm{M}$ & {$[035]$} \\
\hline & & & Breast (MDA) & $0.13 \mu \mathrm{g} / \mathrm{mL}$ & & $2.90 \mu \mathrm{g} / \mathrm{mL}$ & \\
\hline & & & Breast (MCF-7) & $2.46 \mu \mathrm{g} / \mathrm{mL}$ & & $1.14 \mu \mathrm{g} / \mathrm{mL}$ & \\
\hline Trichocarane E (26) & I. fumosorosea & $30 \mathrm{mg} / 200 \mathrm{~g}$ extract & Ovary (SKOV-3) & $1.01 \mu \mathrm{g} / \mathrm{mL}$ & Cisplatin & $3.80 \mu \mathrm{gg} / \mathrm{mL}$ & [67] \\
\hline & & & Cervical (Hela) & $2.32 \mu \mathrm{g} / \mathrm{mL}$ & & $2.24 \mu \mathrm{gg} / \mathrm{mL}$ & \\
\hline & & & Lung (A549) & $1.40 \mu \mathrm{g} / \mathrm{mL}$ & & $2.13 \mu \mathrm{g} / \mathrm{mL}$ & \\
\hline & & & Liver (HepG2) & $1.87 \mu \mathrm{g} / \mathrm{mL}$ & & $0.62 \mu \mathrm{g} / \mathrm{mL}$ & \\
\hline & & & Breast (MDA) & $0.89 \mu \mathrm{g} / \mathrm{mL}$ & & $2.90 \mu \mathrm{gg} / \mathrm{mL}$ & \\
\hline & & & Breast (MCF-7) & $4.38 \mu \mathrm{g} / \mathrm{mL}$ & & $1.14 \mu \mathrm{g} / \mathrm{mL}$ & \\
\hline Trichocarane F (27) & I. fumosorosea & $41 \mathrm{mg} / 200 \mathrm{~g}$ extract & Ovary (SKOV-3) & $1.46 \mu \mathrm{g} / \mathrm{mL}$ & Cisplatin & $3.80 \mu \mathrm{g} / \mathrm{mL}$ & [67] \\
\hline & & & Cervical (Hela) & $4.57 \mu \mathrm{g} / \mathrm{mL}$ & & $2.24 \mu \mathrm{g} / \mathrm{mL}$ & \\
\hline & & & Lung (A549) & $1.66 \mu \mathrm{g} / \mathrm{mL}$ & & $2.13 \mu \mathrm{g} / \mathrm{mL}$ & \\
\hline & & & Liver (HepG2) & $3.66 \mu \mathrm{g} / \mathrm{mL}$ & & $0.62 \mu \mathrm{g} / \mathrm{mL}$ & \\
\hline
\end{tabular}

Note: ni = not informed 
Despite the huge number of fungal bioactive metabolites, there is controversy regarding the consumption or development of new drugs from metabolites biosynthesized by toxin-producing fungi. Terrein (23) and agmatine (28) (Figure 4)are examples of biologically active metabolites produced by Aspergillus, a genus often associated with the production of mycotoxins [71,72]. However, species from Aspergillus and Fusarium genera, known sources of toxins such as zearalenone (29), trichothecenes (30), and fumonisins (31) (Figure 3), have shown a biotechnological potential beyond the production of mycotoxins. For example, azaanthraquinone derivatives, 7-desmethyl-6-methylbostrycoidin (32), and 7-desmethylscorpinone (33) (Figure 4), isolated from F. solani cultures, showed significant activity against tumor cell lines (Table 3) [69].The mycoprotein "Quorn", a popular fungal food for human consumption, is produced using mycelia of Fusarium sp. [72]. Therefore, disregarding the potential of species from mycotoxin-producing genera is unnecessary in the research and industrial development of food products and medicines.

Cancer and neurodegenerative diseases are pathologies targeted by antioxidant therapies, not only for treatment but also for prevention, as proven by pre-clinical, clinical, and epidemiological studies [73]. Although compounds and foods with antioxidant activity have been targeted by many studies [5,74], some brief considerations are worthwhile. Despite encouraging data from several screenings pointing to a very significant number of fungal products with antioxidant activity, it is important to note that most of the experiments in these studies were not applied to tissues and organ systems, and the pharmacokinetic aspects of the absorption of these substances by the human organism were not evaluated [74]. Thus, the straightforward extrapolation of the results of these screenings to in vivo human applications is not possible [75].

Conversely, the in vitro antioxidant profile of a natural product can be improved. This was observed in a study in which three strains of M. circinelloides (CBS 277.49, WJ11, and CBS 108.16) were grown for different time periods (three, five, and seven days) in different culture media (standard Kendrick medium and Ratledge and modified Kendrick and Ratledge media (MKR), with nitrogen deficiency) and evaluated for phenolic compounds and antioxidant capacity. The total phenolics (TPC) and flavonoids (TFC) were improved for CBS 277.49, while CBS 108.16 produced a higher amount of condensed tannins (TCT). The ethanol extract obtained from CBS 277.49 (five days of growth in MKR medium) presented the best results regarding neutralization of the2,2'-Azino-bis(3-ethylbenzothiazoline-6-sulfonic acid) $\left(\mathrm{ABTS}^{+}\right)$radical, copper reducing power, and ferric reducing power. The latter had a higher ferric reducing power than those of the standards BHT and $\alpha$-tocopherol [76].

Despite the relevance of cancer as an NTCD, several other diseases linked to aging limit a healthy life as people age. Accumulated dietary deficiencies throughout life and loss of immunity increase mortality rates associated with non-fatal diseases such as infections. Chronic inflammation is another worrisome condition that increases the risk of developing various pathologies such as hypertension, diabetes, and neurodegenerative diseases [77]. Although early diagnosis and measures to avoid aging-related pathologies and their consequences are essential, drugs for existing diseases continue to be required. Table 4 presents the structures of fungal metabolites associated with the treatment or control of infections, inflammatory and neuroinflammatory conditions, and Alzheimer's disease and examples and extents of the biological activities of these compounds. 
Table 4. Examples of non-cytotoxic biologically active fungal secondary metabolites.

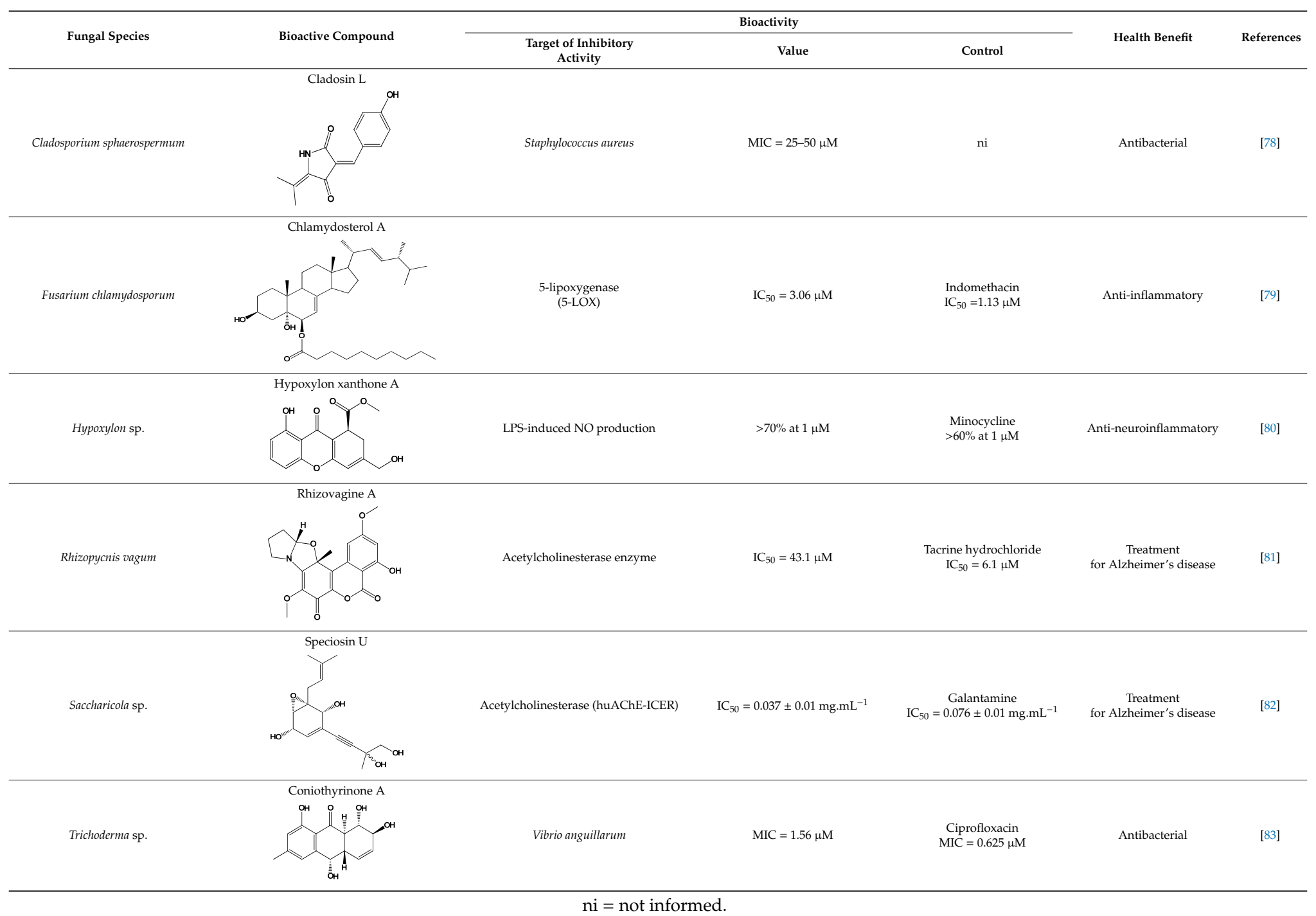


The use of epigenetics for the production of new secondary metabolites through the activation of biosynthetic routes involving transcriptional genes previously silenced is an approach to increase and diversify the production of bioactive secondary metabolites by fungi. The use of a mutant strain of Fusarium graminearum lacking H3K27 methyltransferase after removal of the secondary metabolism repressor kmt6 gene was reported as being advantageous for obtaining 22 metabolites, three of which had not been previously identified to be produced by this species: N-ethyl anthranilic acid (34), $\mathrm{N}$-phenetylacetamide (35), and N-acetyltryptamine (36) (Figure 4). The production of the double mutant kmt6fus 1, with elimination of the production of compounds of the class fusarins, enabled the discovery of two new sesquiterpenes, tricinolone (37) and tricinolonic acid (38) (Figure 4) [84].

\section{Mushrooms as Functional Foods for Preventing Aging-Related Non-Transmissible Chronic Diseases (NTCD)}

The intake of edible mushrooms as functional foods associated with health improvement has been widely described [85]. Some metabolites obtained from mushrooms have been introduced into the market as they have antitumor properties or immunostimulants such as the polysaccharide lentinan produced by the edible mushrooms Lentinula edodes (Shiitake) and G. lucidum. G. lucidum latter is consumed in traditional East Asian medicine as bitter tea (hot aqueous extraction) and can also be obtained as a dry powder. The pharmacological properties of several mushroom metabolites have been demonstrated such as those of polysaccharides produced by G. lucidum, which were able to increase the survival of worms by activating the transcription factors DAF-16/FOXO [86].

Hirsutella sinensis produces polysaccharides with prebiotic properties related to insulin resistance and diabetes control [87,88]. Spermidine (39) (Figure 4) produced by several species [89], proved capable of prolonging the life of mice by reducing histone acetyltransferase EP300 [90], while epidemiological evidence indicates that spermidine (39) intake may also contribute to the reduction of human mortality [91]. Considerable amounts of the metabolite lovastatin (40) (Figure 4), a drug registered as low-density lipoprotein (LDL) cholesterol lowering, were detected in the widely consumed mushrooms Agaricus bisporus ( $30.79 \mathrm{mg} / 100 \mathrm{~g}$ dry weight), Cantharellus cibarius (67.89 mg/100 g dry weight), Imleri abadia (6.21 mg/100 g dry weight), and L. edodes ( $0.95 \mathrm{mg} / 100 \mathrm{~g}$ dry weight) [92].

However, the most prominent example of a mushroom with nutraceutical properties may be Cordyceps militaris, a rare and naturally occurring entomopathogenic medicinal mushroom in the Himalayan Mountains, Tibet, Nepal, and India. Studies have reported that consuming C. militaris extracts significantly increases glucose metabolism, thereby decreasing the glucose level in the blood. In addition, consumption of this mushroom provides protection against diabetic nephropathy [93]. C. militaris produces polysaccharides in the fructification body that are active toward $\alpha$-glucosidase [94] and have immunomodulatory activity; this suggests their incorporation into functional foods and dietary supplements [95]. Anti-adipogenic activity was reported for a fermentation mix containing strawberry, silkworm pupae, and C. militaris [96]. Several nutraceutical products containing Cordyceps are available in the global market. Among the benefits claimed by their manufacturers are the promotion of mental health and benefits to the vascular system ("Cordyceps active"), cognition support ("Mushroom Plus"), anticancer and antioxidant activity ("Bhutan Cordyceps Tea"), strengthening of the cardiovascular system ("MRM CordycepsCS-4 Strain"), and immune system support ("MycoNutri Cordyceps Organic") [97]. Cordycepin (41) (Figure 4) is the main metabolite produced by C. militaris and is very effective in reducing the accumulation of LDL, total cholesterol, triglycerides, and hyperlipidemia caused by high-fat diets [98]. Cordycepin (41) has several pharmacological properties such as anti-inflammatory, immunomodulatory, antioxidant, anti-aging, anticancer, antiviral, cardio, and hepatoprotective properties, among others [97]. This range of activities results in health effects that may help in postponing aging-linked NTCD. C. militaris also has high nutritional value and contains proteins, phenolic compounds, steroids, and lectins [99].

Another mushroom species with high functional and nutraceutical potential of high market value is Agaricus subrufescens (synonymy Agaricus blazei and Agaricus brasiliensis) [100]. It is commercialized 
in several countries such as Brazil (brand name "Sun mushroom"), China (Ji Song Rong), and Japan (Himematsutake) [101]. Sun mushroom contains polyphenols and polysaccharides and is known to decrease oxidative stress and prevent NTCD; it is indicated to have antioxidant, antitumor, anti-inflammatory, and immunomodulatory properties [102].

Another class of bioactive compounds of increasing prominence found in edible mushrooms includes antcins (42) (Figure 4), steroids that contain an ergostane-type skeleton and are produced by Antrodia species such as Antrodia cinnamomea and Antrodia salmomea. Studies suggest that these compounds are promising agents in the treatment of cancer, inflammation, diabetes, and diseases resulting from oxidative stress, among others. The aforementioned species have been historically used in communities of Taiwan for treating various diseases such as diarrhea, abdominal pain, hypertension, dermatological irritation, and intoxication by food, alcohol, and drugs [103]. A study tracking 36,499 middle-aged and elderly Japanese men over an average of 13.2 years found a positive relationship between regular mushroom consumption and decreased incidence of prostate cancer [104]. Table 5 summarizes the classes of compounds and health benefits from some mushroom species cited in this section.

Table 5. Mushroom-originated compounds and health benefits related to non-transmissible chronic diseases (NTCD).

\begin{tabular}{|c|c|c|c|c|c|}
\hline $\begin{array}{l}\text { Mushroom } \\
\text { Species }\end{array}$ & Popular Name & Origin & Related Compounds & Health Benefits & References \\
\hline G. lucidum & Reishi & China and Eastern Asia & Polysaccharides & $\begin{array}{l}\text { Antioxidant activity related to } \\
\text { DAF-16/FOXO activation }\end{array}$ & [85] \\
\hline H.sinensis & Caterpillar & Tibet & Polysaccharides & $\begin{array}{l}\text { Prebiotic properties related to insulin } \\
\text { resistance and diabetes control }\end{array}$ & {$[87,88]$} \\
\hline L.edodes & Shitake & Eastern Asia & Spermidine (39) & $\begin{array}{l}\text { Reduction on age-dependent } \\
\text { memory impairment }\end{array}$ & [91] \\
\hline A. bisporus & Champignon & \multirow{4}{*}{ Eastern Europe } & \multirow{4}{*}{ Lovastatin (40) } & \multirow{4}{*}{ LDL-cholesterol lowering } & [94] \\
\hline C. cibarius & Chanterelle & & & & [92] \\
\hline I. badia & Bay bolete & & & & [92] \\
\hline L. edodes & Shitake & & & & [92] \\
\hline \multirow[b]{2}{*}{ C. militaris } & \multirow[b]{2}{*}{ Caterpillar } & \multirow[b]{2}{*}{ China, Tibet } & Polysaccharides & Immunomodulation improvement & {$[94,95]$} \\
\hline & & & Cordycepin (41) & $\begin{array}{l}\text { Total and LDL-cholesterol lowering, } \\
\text { reduction of hyperlipidemia } \\
\text { caused by high-fat diets }\end{array}$ & [96] \\
\hline A. subrufescens & Sun Mushroom & Eastern North America & $\begin{array}{c}\text { Polyphenols, } \\
\text { polysaccharides }\end{array}$ & $\begin{array}{l}\text { Decrease of oxidative stress, } \\
\text { preventing diseases }\end{array}$ & [100-102] \\
\hline A. cinnamomea & Niu-Chang-Chih & Taiwan & Antcins (42) & like cancer and inflammation & [103] \\
\hline
\end{tabular}

\section{Toward a Sustainable Production of Fungal Metabolites}

As the demand for preventive medicines, nutraceuticals, new drugs, food additives, and other health-related products of natural origin grows, the need for scaling up is also increasing. For bioactive metabolites of plant origin, efforts to increase production may be slow because production sometimes dependent on the seasonality of plants and a long plant growth period. Thus, efforts to increase the production of bioactive compounds have been directed toward microorganism-based options, such as metabolic engineering. Modifications in the culturing of fungi have been successful in the yield improvement of biomass and bioactive compounds. Moreover, special consideration is being given to endophytic fungi, especially those able to produce metabolites biosynthesized by their host plants. Table 6 shows some interesting examples of bioactive compounds produced by endophytic fungi after optimization of fermentation conditions. The good outcomes in this area were exemplified by Torres-Mendoza et al. [105] who reported, from 2001 to 2019, 224 patents related to metabolites from endophytic fungi applied to agricultural, biotechnology, pharmaceutical, and food industries, most of which used species from the Aspergillus, Fusarium, Trichoderma, Penicillium, and Phomopsis genera. 
Table 6. Bioactive compounds produced by endophytic fungi under different fermentation conditions.

\begin{tabular}{|c|c|c|c|c|c|c|}
\hline Fungal Species & Host Plant & Target Compound & Health Benefit & Methodology & Target Parameters & Reference \\
\hline A.terreus & Coconut tree & $\mathrm{L}^{\text {-Asparaginase }}$ & $\begin{array}{c}\text { Treatment of acute } \\
\text { lymphocytic leukemia }\end{array}$ & $\begin{array}{c}\text { Factorial experimental design. } \\
\text { Increase of scale(5-1 bioreactor system). }\end{array}$ & $\begin{array}{c}\mathrm{pH} \text {, temperature, } \\
\text { inoculum concentration. }\end{array}$ & [106] \\
\hline F. solani & Chonemorpha fragrans & Camptothecin & Anticancer & $\begin{array}{l}\text { Box-Behnken design using } \\
\text { one factor at a time } \\
\text { method. }\end{array}$ & $\begin{array}{l}\text { Carbon and nitrogen sources, ethanol } \\
\text { concentration, } \mathrm{pH} \text {, temperature, } \\
\text { stirring speed, incubation period, } \\
\text { precursors and elicitors. }\end{array}$ & [107] \\
\hline Penicillium bilaiae & Phoenix dactylifera & Acidic protease & Increasing in food digestibility & $\begin{array}{l}\text { Response surface methodology. } \\
\text { Plackett-Burman design. } \\
\text { Box-Behnken design. }\end{array}$ & $\begin{array}{l}\text { Temperature, initial pH, carbon and nitrogen } \\
\text { sources, metal ions, detergents and } \\
\text { enzyme inhibitors. }\end{array}$ & [108] \\
\hline P. ostreatus & ni & \multirow{2}{*}{ Lovastatin (40) } & \multirow{2}{*}{ Anti-hypercholesterolemic } & $\begin{array}{l}\text { Response surface } \\
\text { methodology. }\end{array}$ & $\begin{array}{l}\text { Nutrients, particle size of the solid substrate, } \\
\text { temperature, incubation time. }\end{array}$ & [109] \\
\hline Meyerozymaguilliermondii & leaves of Hibiscus rosa-sinensis & & & $\begin{array}{l}\text { One parameter at time } \\
\text { approach. }\end{array}$ & $\begin{array}{l}\text { Nutrients, } \mathrm{pH} \text {, inoculum size, temperature, } \\
\text { addition of metallic ions, modulators, precursors. }\end{array}$ & [110] \\
\hline A.niger & ni & Urease & Diuretic & $\begin{array}{l}\text { Response surface } \\
\text { methodology. }\end{array}$ & $\begin{array}{l}\text { Strains, incubation time, temperature, } \mathrm{pH}, \\
\text { biomass, inoculum size, } \\
\text { nitrogen content and moisture. }\end{array}$ & [111] \\
\hline Spissiomycesendophytica & Balanophorafungosa & Melanin & $\begin{array}{l}\text { Radioprotective, thermoregulator, } \\
\text { antitumor, and antiviral }\end{array}$ & $\begin{array}{l}\text { One parameter at time } \\
\text { approach. }\end{array}$ & $\begin{array}{l}\text { Inhibitors, culture medium, } \\
\text { temperature, } \mathrm{pH} \text {. }\end{array}$ & [112] \\
\hline E. nigrum & Taxus baccata & Taxol & Anticancer & $\begin{array}{l}\text { One parameter at a time approach. } \\
\text { Mutant strains. }\end{array}$ & $\begin{array}{c}\text { Culture medium, stirring speed, temperature, } \\
\text { incubation period, } \mathrm{pH} \text {, medium volume, } \\
\text { inoculum age, inoculum size, carbon source, } \\
\text { nitrogen source, phosphorus source, } \\
\text { gamma radiation dose. }\end{array}$ & [113] \\
\hline Alternaria brassicae & Huperzia serrata & Huperzine A & Acetylcholinesterase inhibitor & $\begin{array}{l}\text { Multifactorial statistical approaches. } \\
\text { Plackett-Burman. } \\
\text { Central composite designs. }\end{array}$ & $\begin{array}{l}\text { Culture medium composition, medium volume, } \\
\text { inoculum age, inoculum size, incubation period, } \\
\text { ethanol addition, } \\
\text { pH, temperature. }\end{array}$ & [114] \\
\hline F. oxysporum & Dioscoreazingiberensis & Diosgenin & $\begin{array}{l}\text { Anti-cancer, anti-thrombic, anti-diabetic, } \\
\text { cardioprotective, osteoarthritis } \\
\text { protective activity }\end{array}$ & One parameter at time approach. & Culture medium, antibiotics, temperature. & [115] \\
\hline E. nigrum & Terminalia arjuna & Digoxin & $\begin{array}{l}\text { Regulating the heart rhythm and } \\
\text { strengthening heart diffusion }\end{array}$ & One parameter at time approach. & $\begin{array}{c}\text { Culture medium, temperature, elicitors, } \\
\text { incubation time, pH, medium volume, inoculum } \\
\text { age, inoculum size, } \\
\text { gamma irradiation mutagenesis. }\end{array}$ & [113] \\
\hline Penicillium mallochii & $\begin{array}{l}\text { A beech tree bark from } \\
\text { Balikesir, Turkey }\end{array}$ & Orange-red pigment & $\begin{array}{l}\text { Decreasing in allergic responses to } \\
\text { synthetic pigments }\end{array}$ & One parameter at time approach. & $\begin{array}{l}\text { Culture medium, } \mathrm{pH} \text {, } \\
\text { temperature. }\end{array}$ & [116] \\
\hline Tausonia pullulans & Vinca minor & Vincamine & $\begin{array}{l}\text { Improvement of cerebrovascular and } \\
\text { cognitive disorders and reduction the } \\
\text { effects of certain types of stroke }\end{array}$ & Protoplasts optimization. & $\begin{array}{l}\text { Incubation time, temperature, modulators, } \\
\text { protoplast inactivation method (heat, ultraviolet, } \\
\text { microwave, sodium nitrite, and diethyl sulfate). }\end{array}$ & [117] \\
\hline
\end{tabular}

$$
\text { ni }=\text { not informed. }
$$


Yield enhancement in microbial production is one of the most challenging issues, but good progress has been reported. The production of fungal metabolites can also be optimized by co-cultivation with other fungal or bacterial species and variation of chemical parameters, such as composition of the culture medium, and physical parameters, such as temperature, $\mathrm{pH}$, stirring speed, intensity and color of light, and oxygenation. The metabolic modulation resulting from these approaches depends on the fungal species; thus different fungi have been explored to produce fungal metabolites with new industrial applications around the world [38].

Biosynthesis of the natural polyamide agmatine (28) by A. oryzae, a fungus generally recognized as safe, was described during the fermentative process of sake production (Japanese rice wine) [118]. Optimization of the initial yield of agmatine (28) produced by A. oryzae in the presence of S. cerevisiae in a solid state ( $3.5 \mathrm{mM}$ agmatine) was achieved by varying some fermentative parameters. At $\mathrm{pH} 5.3$, the production of agmatine (28) increased to $6.3 \mathrm{mM}$. An increase of over $100 \%$ in the initial productivity was obtained by adding L-lactic ( $\mathrm{pH} 3.0,8.2 \mathrm{mM}$ agmatine), succinic acid ( $\mathrm{pH} 3.5,8.7 \mathrm{mM}$ agmatine), and citric acid (2) ( $\mathrm{pH} 3.2,8.3 \mathrm{mM}$ agmatine) in the fermentation medium. Therapeutic evidences indicate that agmatine (28) is a promising lead compound against several NTCD that affect the central nervous system, such as Alzheimer's disease [119]. In 2019 only, the number of people affected by dementia was estimated at 50 million, with the worrying forecast of this number to be trebled by 2050 [120]. Therefore, new molecules for the treatment of Alzheimer's disease and other types of dementia are highly desired. The pharmacological properties and yield of agmatine (28) in fermentation by $A$. oryzae suggest the possibility of its incorporation into nutraceuticals [119]. In excess, agmatine (28) may present toxicity and can enhance the toxic action of other biogenic amines, such as histamine and tyramine, produced by the decarboxylation of amino acids by food-fermenting microorganisms. Therefore, determining a proper intake for agmatine (28) is necessary to mitigate risks and allows for the numerous aforementioned health benefits [16].

The preference for faster, less expensive, and green approaches has sped up research on bioactive fungal metabolites. Some promising analytical tools, such as matrix-assisted laser desorption ionization time-of-flight mass spectrometry (MALDI-ToF MS), have been useful for addressing some bottleneck problems in this area, such as fungal identification. Genetic and morphological methods, although very efficient, require expertise, time, and resources that may be saved by the use of analytical instrumentation [121]. Such improvements start during screening steps, in the initial laboratory prospection of relevant species and promising fermentative conditions, and continue to the production steps, with the use of alternative substrates for fungal growth, such as agro industrial residues, towards a circular economy. Thus, extracts intended for screening are prepared on a reduced scale, using lower amounts of reagents, such as solvents, during extraction. In addition, modern analytical tools coupled with hyphenated techniques have been recently used for the analysis of a greater number of extracts, without the need for prior isolation of fungal metabolites from extracts. Biochemometrically derived fingerprints obtained by gas chromatography, high-performance liquid chromatography, MS, and nuclear magnetic resonance spectroscopy (NMR), together with statistical analysis also enable the establishment of straightforward associations between metabolite content and biological activities detected for a large number of crude extracts [70,122].

Although MS is the most widely used technique for this kind of analysis [123], NMR, in particular ${ }^{1} \mathrm{H}$ NMR metabolomic analysis, has gained ground by enabling the nondestructive identification of molecules in complex mixtures originating from various biological materials, such as plants and fungi extracts, foods, biological fluids, and tissues [124,125]. NMR is comparable to MS in criteria, such as efficiency, speed, reproducibility, and ease of sample preparation; however, it has advantages in terms of sample recovery and isotope detection. It is also independent of ionization potential and does not require complex internal standards [126]. Bi-dimensional biochemometric NMR evaluation of the crude extract of a marine-derived strain of P. chrysogenum enabled the attribution of the anti-proliferative activity of the extract against breast cancer cell lines to ergosterol (43) (Figure 4; Table 3), a structural metabolite common in fungi [70]. In addition, other metabolites of the ergostane 


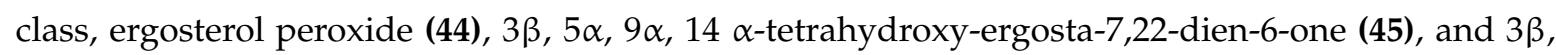
$5 \alpha, 9 \alpha$-trihydroxy-ergosta-7,22-dien-6-one (46) (Figure 4), were detected as metabolites of the edible mushroom $V$. volvacea and proved to be active against human cancer cell lines (Table 3) [68].

An interesting application of NMR-based metabolomics for the comparison and origin identification of edible mushrooms was reported. Multivariate analyses, such as PCA, were used to compare the chemical profiles of species, enabling the differentiation of Kuehneromyces mutabilis and Hypholom acapnoides, and the direct identification of 17 secondary metabolites in their extracts. Statistically significant differences were observed inthe ${ }^{1} \mathrm{H}$ NMR data in the variation of composition based on the collection site and restrictedness of metabolites in K. mutabilis. Upon comparing H. capnoides and K. mutabilis, a higher diversity of sugars was observed in H. capnoides, while K. mutabilis presented significantly higher amounts of some organic compounds, such as fumaric acid (3), showing the versatility of the ${ }^{1} \mathrm{H}$ NMR technique for comparing fungi in terms of metabolites [127].

Other sophisticated approaches combining UPLC-ESI-TOF/MS, differential off-line LC-NMR, and quantitative ${ }^{1} \mathrm{H}$ NMR (qHNMR) analysis were used to identify D-Phe-L-Val-D-Val-L-Tyr (47), D-Phe-L-Val-D-Val-L-Phe (48), and cis-bis(methylthio)silvatin (49) (Figure 4) in the aerobic fermentation of Penicillium roqueforti with and without L-Tryptophan enrichment. Another metabolite, roquefortine C (50) (Figure 4), was identified as an antimicrobial agent against Bacillus subtilis and E. coli [126]. ${ }^{1} \mathrm{H}$ NMR-based metabolomics, applied in a study on extracts of 11 species of edible mushrooms, identified dry Pleurotus geesteranum and Hericium erinaceus and fresh Pleurotus sapidus as the most prominent species in terms of metabolite production. In addition, the use of ${ }^{1} \mathrm{H}$ NMR led to the detection of more than 100 different metabolites of interest to the food industry including trehalose (51), mannitol (52), and glucose (53) (Figure 1). The analysis also showed high levels of carbohydrates and proteins, in addition to considerable amounts of vitamins A (54) and C (55) (Figure 1) and amino acids as nutritional compounds [14]. Therefore, NMR-based metabolomics has been successful in selecting fungi with outstanding potential for further technological development. Metabolomic tools have also been applied for the evaluation of organoleptic properties and interference of external factors with food quality [128] and nutrient quantification such as in the determination of the nutritional contents of 11 Capsicum annuum cultivars in terms of ascorbic acid (vitamin C) (55) [129]. In the near future, once there is sufficient data in this area, these useful metabolomic tools could be applied in several meta-studies such as for the determination of vitamin C (55) content in edible mushrooms. One study [130] reported vitamin C contents between $31.16 \pm 0.93$ (Calvatia gigantea) and $108.11 \pm 3.22$ (Lepis tagilva) $\mathrm{mg} / \mathrm{kg}$ dry matter. In another study [14], the vitamin C contents ranged from 0.5 to $111.4 \mathrm{mg} / 100 \mathrm{~g}$ dry weight. The highest levels of vitamin $C$ were produced by the species $D$. indusiata and A. subrufescens at 111.4 and $69.7 \mathrm{mg} / 100 \mathrm{~g}$ dry weight, respectively [14], values close to the daily levels of vitamin C (55) recommended in some countries (75 to $110 \mathrm{mg}$ ) [131].

Metabolomic approaches have also been applied to the quantification of aflatoxins in industrialized baby food [132], to determine adulteration and its effect on the safety of nutraceuticals [133], and for differentiating extracts of various biomaterials such as crops [134] and fungi [14].

While metabolomic tools provide speed for research, technological development for future industrial applications of fungal metabolites must consider that the modern economy is increasingly challenged to transform traditional processes into sustainable production chains, minimizing waste, and reusing biomass for applications in the food and drug industries, even for well-established processes such as citric acid (2) production. The global market value of citric acid (2) was estimated to increase to USD 3.6 billion in 2020 and maintain an annual growth of $5 \%$ until 2025. Despite the successful industrial experience for citric acid (2) production, research to increase sustainability in bio-refineries is ongoing, opening new possibilities such as clustering-related fermentation production including olive oil and wine to reach models for circular bioeconomy [135].

Fortunately, the production of nutraceuticals and functional foods from biomass, extracts, and fungal metabolites greatly addresses the challenge of sustainability improvement, allowing the incorporation of low-cost, underutilized, and abundant materials into the industrial fermentation 
process. Many agro-industrial residues available all over the world are sources of peptides, prebiotic dietary fibers, and hydrolyzed or smaller organic molecules such as phenolics, carotenoids, and tocopherols, among other classes. These features make them good materials for fungal cultivation as well as interesting substrates for the production of bioactive components from macromolecules $[59,136]$. For example, fermentation of pomegranate bark residue by $A$. niger resulted in the production of citric acid (2) with reduced production costs, while adding value to a residue usually directed for disposal [137]. High yields (7.8 to $14.4 \mathrm{~g} / \mathrm{L}$ ) of dry biomass, with protein contents ranging from 33.8 to $50.8 \%$, and ethanol were recovered from the fermentation of effluents from the wheat starch industry by the fungi $A$. oryzae and R. oryzae. This kind of process contributes to the development of a circular economy, because the large volume and high chemical demand of oxygen in effluents from the starch industry represent an environmental burden and an additional cost as they create a need for effluents to be treated before being discarded [138]. The filamentous fungi Actinomucor elegans and Umbelopsis isabelin were simultaneously used for the enrichment of white grape-producing bagasse, a residue with little nutritional attractiveness. The fungi were able to increase the $\gamma$-linolenic acid and carotenoid contents, improving the nutritional content of bagasse, and thus creating the possibility of reintroducing bagasse into the production chain as a low-cost functional food for humans [139].

\section{Conclusions}

Fungi and their metabolites have important industrial applications in high-value-added products and have potential for the development of nutraceuticals that can contribute to the prevention of NTCD and improve health, especially in terms of human aging. In addition, fungi are suitable in the production of natural food additives such as colorants and stabilizers that have lower health risks than synthetic food additives, and bioactive metabolites for pharmacological use such as enzymes, statins, and antitumor agents. Fungal antioxidants have applications in both food preservation and the combat of oxidative stress in the human body, with positive outcomes for several diseases such as cancer. The use of metabolic engineering techniques has facilitated the overcoming of some obstacles to explore the pharmacological potential of fungi, even those producing toxic substances such as some species of the genera Monascus, Aspergillus, and Fusarium. Modern approaches have been successfully utilized to evaluate the interference of additives derived from fungi with the organoleptic properties and quality of food. Strategies currently available for scaling up metabolite production include direct genetic alteration with tools such as CRISPR-Cas9 and gene recombination. Research on the use of agro-industrial byproducts for sustainable fungal fermentation has shed light on its remarkable economic importance to the production of natural additives, food, drugs, and nutraceuticals. Further in vivo antioxidant activity studies of fungal metabolites are still scarce; however, new insights are required to expand the use of metabolites from filamentous fungi to improve human health in the 21st century.

Author Contributions: All authors participated in the layout of this review. J.A.T., B.V.R.B., B.d.A.M., C.P.G., and M.A.F.M. identified the literature for review and drafted the manuscript. In addition, J.A.T. conceived and critically revised the manuscript, B.V.R.B. and B.d.A.M. provided the tables and figures, and C.P.G. and M.A.F.M. formatted the document. All authors have read and approved the final version of the manuscript.

Funding: The authors gratefully acknowledge financial support from the Brazilian Agencies Fundação de Amparo à Pesquisa do Estado de Minas Gerais (FAPEMIG PPM-00255-18); Conselho Nacional de Desenvolvimento Científico e Tecnológico (CNPq Grants 304922/2018-8, 141601/2018-3, 142517/2018-6, 121994/2019-8); the National Institute of Science and Technology-INCT BioNat/CNPq (Grant 465637/2014-0); and the Coordenação de Aperfeiçoamento de Pessoal de Nível Superior (CAPES)-Finance Code 001.

Acknowledgments: We thank Michel Almeida for kindly preparing the graphical abstract illustration.

Conflicts of Interest: The authors declare no conflict of interest. 


\section{References}

1. Piffieri, F.; Aujard, F. Caloric restriction, longevity and aging: Recent contributions from human and non-human primate studies. Prog. Neuropsychopharmacol. Biol. Psychiatry 2019, 95, 109702. [CrossRef] [PubMed]

2. Aiello, A.; Accardi, G.; Caruso, C.; Candore, G. Effects of nutraceuticals of Mediterranean diet on aging and longevity. In The Mediterranean Diet: An Evidence-Based Approach, 2nd ed.; Preedy, V.R., Wastson, R.R., Eds.; Academic Press: Cambridge, MA, USA, 2020; pp. 547-553. [CrossRef]

3. Zhang, Z.; He, S.; Cao, X.; Ye, Y.; Yang, L.; Wang, J.; Liu, H.; Sun, H. Potential prebiotic activities of soybean peptides Maillard reaction products on modulating gut microbiota to alleviate aging-related disorders in D-galactose-induced ICR mice. J. Funct. Foods 2020, 65, 103729. [CrossRef]

4. Cava, E.; Fontana, L. Will calorie restriction work in humans? Aging 2013, 5, 507-514. [CrossRef] [PubMed]

5. Martel, J.; Ojcius, D.M.; Ko, Y.F.; Chang, C.J.; Young, J.D. Antiaging effects of bioactive molecules isolated from plants and fungi. Med. Res. Rev. 2019, 39, 1515-1552. [CrossRef] [PubMed]

6. Sachdeva, V.; Roy, A.; Bharadvaja, N. Current prospects of nutraceuticals: A review. Curr. Pharm. Biotechnol. 2020, 21, 884-896. [CrossRef]

7. Ruchi, S. Role of nutraceuticals in health care: A review. Int. J. Green Pharm. 2017, 11, S385-S394. [CrossRef]

8. Padmavathi, D. A general review on "nutraceuticals": Its golden health impact over human community. Int. J. Food. Sci. Nut. 2018, 3, 214-217.

9. Tomova, A.; Bukovsky, I.; Rembert, E.; Yonas, W.; Alwarith, J.; Barnard, N.D.; Kahleova, H. The effects of vegetarian and vegan diets on gut microbiota. Front. Nutr. 2019, 6, 47. [CrossRef]

10. Meyer, V.; Basenko, E.Y.; Philipp Benz, J.; Braus, G.H.; Caddick, M.X.; Csukai, M.; Vries, R.P.; Endy, D.; Frisvad, J.C.; Gunde-Cimerman, N.; et al. Growing a circular economy with fungal biotechnology: A white paper. Fungal Biol. Biotechnol. 2020, 7, 1-23. [CrossRef]

11. Kumari, K. Mushrooms as source of dietary fiber and its medicinal value: A review article. J. Pharmacogn. Phytochem. 2020, 9, 2075-2078.

12. Kato, T.; Azegami, J.; Yokomori, A.; Dohra, H.; Enshasy, H.A.; Park, E.Y. Genomic analysis of a riboflavin-Overproducing Ashbya gossypii mutant isolated by disparity mutagenesis. BMC Genom. 2020, 21, 1-17. [CrossRef] [PubMed]

13. Jesus, L.F.M.C. Produção de $\beta$-Galactosidase Por Fungos Filamentosos: Screening, Purificação e Caracterização Bioquímica. Master's Thesis, Universidade Estadual Paulista "Julio Mesquita Filho", UNESP, São Paulo, Brazil, 2020.

14. Liu, D.; Chen, Y.Q.; Xiao, X.W.; Zhong, R.T.; Yang, C.F.; Liu, B.; Zhao, C. Nutrient properties and nuclear magnetic resonance-based metabonomic analysis of macrofungi. Foods 2019, 8, 397. [CrossRef] [PubMed]

15. Koutrotsios, G.; Kalogeropoulos, N.; Stathopoulos, P.; Kaliora, A.C.; Zervakis, G.I. Bioactive compounds and antioxidant activity exhibit high intraspecific variability in Pleurotusostreatus mushrooms and correlate well with cultivation performance parameters. World J. Microb. Biotechnol. 2017, 33, 98. [CrossRef] [PubMed]

16. Akasaka, N.; Fujiwara, S. The therapeutic and nutraceutical potential of agmatine, and its enhanced production using Aspergillus oryzae. Amino Acids 2020, 52, 181-197. [CrossRef]

17. Chan, L.G.; Dias, F.F.; Saarni, A.; Cohen, J.; Block, D.; Taha, A.Y.; de Moura Bell, J.M. Scaling up the bioconversion of cheese whey permeate into fungal oil by Mucor circinelloides. J. Am. Oil Chem. Soc. 2020, 97, 703-716. [CrossRef]

18. Mamani, L.D.G.; Magalhães, A.I., Jr.; Ruan, Z.; de Carvalho, J.C.; Soccol, C.R. Industrial production, patent landscape, and market trends of arachidonic acid-rich oil of Mortierella alpina. Biotech. Res. Innov. 2019, 3, 103-119. [CrossRef]

19. Anand, S.; Singh, K.S.; Aggarwal, D. Expanding Avenues for Probiotic Yeast. In Microbial Cell Factories, 1st ed.; Sharma, D., Saharan, B.S., Eds.; CRC Press: Boca Raton, FL, USA, 2018; pp. 125-141.

20. Baggio, L.M.; Panagio, L.A.; Gasparin, F.G.M.; Sartori, D.; Celligoi, M.A.P.C.; Baldo, C. Production of fibrinogenolytic and fibrinolytic enzymes by a strain of Penicillium sp. isolated from contaminated soil with industrial effluent. Acta Sci. Health Sci. 2019, 41, e40606. [CrossRef]

21. Zhang, S.; Wang, Y.; Zhang, N.; Sun, Z.; Shi, Y.; Cao, X.; Wang, H. Purification and characterization of a fibrinolytic enzyme from Rhizopus microsporus var. tuberosus. Food Technol. Biotech. 2015, 53, $243-248$. [CrossRef] 
22. Huang, Z.; Brennan, C.S.; Zheng, H.; Mohan, M.S.; Stipkovits, L.; Liu, W.; Kulasiri, D.; Guan, W.; Zhao, H.; Liu, J. The effects of fungal lipase-treated milk lipids on bread making. LWT 2020, 109455. [CrossRef]

23. Hjortmo, S.B.; Hellström, A.M.; Andlid, T.A. Production of folates by yeasts in Tanzanian fermented togwa. FEMS Yeast Res. 2008, 8, 781-787. [CrossRef]

24. Copetti, M.V. Fungi as industrial producers of food ingredients. Curr. Opin. Food Sci. 2019, 25, 52-56. [CrossRef]

25. Dikshit, R.; Tallapragada, P. Comparative Study of Natural and Artificial Flavoring Agents and Dyes. In Natural and Artificial Flavoring Agents and Food Dyes; Grumezescu, A.M., Holban, A.M., Eds.; Elsevier: London, UK, 2018; Volume 7, pp. 83-111.

26. Tkaczyk, A.; Mitrowska, K.; Posyniak, A. Synthetic organic dyes as contaminants of the aquatic environment and their implications for ecosystems: A review. Sci. Total Environ. 2020, 717, 137222. [CrossRef] [PubMed]

27. Venil, C.K.; Velmurugan, P.; Dufossé, L.; Devi, P.R.; Ravi, A.V. Fungal Pigments: Potential coloring compounds for wide ranging applications in textile dyeing. J. Fungi 2020, 6, 68. [CrossRef]

28. [ACS] American Chemical Society. Dyes, Pigments and Inks. 2020. Available online: https://www. acs.org/content/acs/en/careers/college-to-career/chemistry-careers/dyes-pigments-ink.html (accessed on 8 September 2020).

29. [FDA] U.S. Food and Drug Administration. Color Additives History. 2017. Available online: https://www.fda.gov/industry/color-additives/color-additives-history\#: \{\}:text=A\%20color\%20additive $\%$ 2C\%20as \%20defined,or\%20to\%20the\%20human \%20body.\&text=One \%20of\%20the \%20U.S.\%20Food, are \% 20safely\%20and\%20appropriately\%20used (accessed on 8 September 2020).

30. Kalra, R.; Conlan, X.A.; Goel, M. Fungi as a potential source of pigments: Harnessing filamentous fungi. Front. Chem. 2020, 8. [CrossRef] [PubMed]

31. Dufossé, L. Microbial production of food grade pigments. Food Technol. Biotech. 2006, 44, 313-321.

32. Sen, T.; Barrow, C.J.; Deshmukh, S.K. Microbial pigments in the food industry-Challenges and the way forward. Front. Nutr. 2019, 6. [CrossRef]

33. Lebeau, J.; Petit, T.; Clerc, P.; Dufossé, L.; Caro, Y. Isolation of two novel purple naphtoquinone pigments concomitant with the bioactive red bikaverin and derivates thereof produced by Fusarium oxysporum. Biotech. Prog. 2019, 35. [CrossRef]

34. Slack, G.J.; Puniani, E.; Frisvad, J.C.; Samson, R.A.; Miller, J.D. Secondary metabolites from Eurotium species, Aspergillus calidoustus and A. insuetus common in Canadian homes with a review of their chemistry and biological activities. Mycol. Res. 2009, 113, 480-490. [CrossRef]

35. Mondal, S.; Pandit, S.G.; Puttananjaiah, M.H.; Harohally, N.V.; Dhale, M.A. Structural and functional characterization of new pigment molecule monashin from Monascuspurpureus CFR410-11. Process. Biochem. 2019, 82, 173-178. [CrossRef]

36. Wu, H.C.; Cheng, M.J.; Wu, M.D.; Chen, J.J.; Chen, Y.L.; Chang, H.S.; Chen, K.P. Secondary metabolites from the fermented rice of the fungus Monascus purpureus and their bioactivities. Nat. Prod. Res. 2019, 33, 3541-3550. [CrossRef]

37. Kraboun, K.; Kongbangkerd, T.; Rojsuntornkitti, K.; Phanumong, P. Factors and advances on fermentation of Monascus sp. for pigments and monacolin K production: A review. Int. Food. Res. J. 2019, 26, 751-761.

38. Shi, Y.C.; Pan, T.M.; Liao, V.H.C. Monascin from Monascus-fermented products reduces oxidative stress and amyloid-beta toxicity via DAF-16/FOXO in Caenorhabditis elegans. J. Agric. Food. Chem. 2016, 64, 7114-7120. [CrossRef] [PubMed]

39. Hsu, W.H.; Chen, T.H.; Lee, B.H.; Hsu, Y.W.; Pan, T.M. Monascin and ankaflavin act as natural AMPK activators with $\operatorname{PPAR} \alpha$-agonist activity to down-regulate nonalcoholic steatohepatitis in high-fat diet-fed C57BL/6 mice. Food Chem. Toxicol. 2014, 64, 94-103. [CrossRef] [PubMed]

40. Venkatachalam, M.; Shum-Chéong-Sing, A.; Dufossé, L.; Fouillaud, M. Statistical optimization of the physico-chemical parameters for pigment production in submerged fermentation of Talaromyces albobiverticillius 30548. Microorganisms 2020, 8, 711. [CrossRef]

41. Palacio-Barrera, A.M.; Areiza, D.; Zapata, P.; Atehortúa, L.; Correa, C.; Peñuela-Vásquez, M. Induction of pigment production through media composition, abiotic and biotic factors in two filamentous fungi. Biotechnol. Rep. 2018, 20, e00308. [CrossRef] 
42. Osemwegie, O.O.; Adetunji, C.O.; Ayeni, E.A.; Adejobi, O.I.; Arise, R.O.; Nwonuma, C.O.; Oghenekaro, A.O. Exopolysaccharides from bacteria and fungi: Current status and perspectives in Africa. Heliyon 2020, 6, e04205. [CrossRef]

43. Mahapatra, S.; Banerjee, D. Fungal exopolysaccharide: Production, composition and applications. Microbiol. Insights 2013, 6, 1-16. [CrossRef]

44. Iyyappan, J.; Bharathiraja, B.; Baskar, G.; Kamalanaban, E. Process optimization and kinetic analysis of malic acid production from crude glycerol using Aspergillus niger. Bioresour. Technol. 2019, 281, 18-25. [CrossRef]

45. Saeed, S.; Aslam, S.; Mehmood, T.; Naseer, R.; Nawaz, S.; Mujahid, H.; Firyal, S.; Anjum, A.A.; Sultan, A. Production of gallic acid under solid-state fermentation by utilizing waste from food processing industries. Waste Biomass Valoriz. 2020, 1-9. [CrossRef]

46. Costa, C.R.L.M.; Menolli, R.A.; Osaku, E.F.; Tramontina, R.; Melo, R.H.; Amaral, A.E.; Duarte, P.A.D.; Carvalho, M.M.; Smiderle, F.R.; Silva, J.L.C.; et al. Exopolysaccharides from Aspergillus terreus: Production, chemical elucidation and immunoactivity. Int. J. Biol. Macromol. 2019, 139, 654-664. [CrossRef]

47. Fooladi, T.; Soudi, M.R.; Alimadadi, N.; Savedoroudi, P.; Heravi, M.M. Bioactive exopolysaccharide from Neopestalotiopsis sp. strain SKE15: Production, characterization and optimization. Int. J. Biol. Macromol. 2019, 129, 127-139. [CrossRef]

48. Xu, X.; Xu, R.; Jia, Q.; Feng, T.; Huang, Q.; Ho, C.T.; Song, S. Identification of dihydro- $\beta$-ionone as a key aroma compound in addition to $\mathrm{C} 8$ ketones and alcohols in Volvariella volvacea mushroom. Food Chem. 2019, 293, 333-339. [CrossRef] [PubMed]

49. Zeng, X.; Zeng, H.; Meng, Y.; Xu, D.; Zhang, B.; Xin, B.; Liu, S.; Zhai, B.; Yu, F.; Zhu, M.; et al. Continuous natamycin production by using immobilized Streptomyces gilvosporeus Z8 via repeated batch culture. J. Chem. Technol. Biotechnol. 2020, 95, 73-77. [CrossRef]

50. Bin, C.; Fangming, Y.; Zhi, J. Mogroside V-producing endophytic fungi isolated from Siraitia grosvenorii. Planta Med. 2020, 86, 983-987. [CrossRef] [PubMed]

51. Kallscheuer, N. Engineered microorganisms for the production of food additives approved by the European Union-A systematic analysis. Front. Microbiol. 2018, 9, 1746. [CrossRef]

52. Kovilein, A.; Kubisch, C.; Cai, L.; Ochsenreither, K. Malic acid production from renewables: A review. J. Chem. Technol. Biotechnol. 2019, 95, 513-526. [CrossRef]

53. Li, Y.; Lin, Z.; Huang, C.; Zhang, Y.; Wang, Z.; Tang, Y.; Chen, T.; Zhao, X. Metabolic engineering of Escherichia coli using CRISPR-Cas9 mediated genome editing. Metab. Eng. 2015, 31, 13-21. [CrossRef] [PubMed]

54. Tramontin, L.R.R.; Kildegaard, K.R.; Sudarsan, S.; Borodina, I. Enhancement of astaxanthin biosynthesis in oleaginous yeast Yarrowialipolytica via microalgal pathway. Microorganisms 2019, 7, 472. [CrossRef] [PubMed]

55. Harith, Z.T.; Charalampopoulos, D.; Chatzifragkou, A. Rapeseed meal hydrolysate as substrate for microbial astaxanthin production. Biochem. Eng. J. 2019, 151, 107330. [CrossRef]

56. Hwang, S.W.; Choi, H.I.; Sim, S.J. Acidic cultivation of Haematococcuspluvialis for improved astaxanthin production in the presence of a lethal fungus. Bioresour. Technol. 2019, 278, 138-144. [CrossRef] [PubMed]

57. Ip, P.F.; Wong, K.H.; Chen, F. Enhanced production of astaxanthin by the green microalga Chlorella zofingiensis in mixotrophic culture. Process. Biochem. 2004, 39, 1761-1766. [CrossRef]

58. Tang, D.Y.Y.; Khoo, K.S.; Chew, K.W.; Tao, Y.; Ho, S.H.; Show, P.L. Potential utilization of bioproducts from microalgae for the quality enhancement of natural products. Bioresour. Technol. 2020, 304, 122997. [CrossRef] [PubMed]

59. Villena, G.K.; Kitazono, A.A.; Hernández-Macedo, M.L. Bioengineering Fungi and Yeast for the Production of Enzymes, Metabolites, and Value-Added Compounds. In Fungal Biotechnology and Bioengineering; Hesham, A.E.L., Upadhyay, R.S., Sharma, G.D., Manoharachary, C., Gupta, V.K., Eds.; Springer: Cham, Switzerland, 2020; pp. 209-237. [CrossRef]

60. Sun, X.; Su, X. Harnessing the knowledge of protein secretion for enhanced protein production in filamentous fungi. World J. Microbiol. Biotech. 2019, 35, 54. [CrossRef] [PubMed]

61. Kumitch, H.M.; Stone, A.; Nosworthy, M.G.; Nickerson, M.T.; House, J.D.; Korber, D.R.; Tanaka, T. Effect of fermentation time on the nutritional properties of pea protein-enriched flour fermented by Aspergillus oryzae and Aspergillus niger. Cereal Chem. 2019, 97, 104-113. [CrossRef] 
62. Gmoser, R.; Fristedt, R.; Larsson, K.; Undeland, I.; Taherzadeh, M.J.; Lennartsson, P.R. From stale bread and brewers spent grain to a new food source using edible filamentous fungi. Bioengineered 2020, 11, 582-598. [CrossRef]

63. Asfour, H.Z.; Awan, Z.A.; Bagalagel, A.A.; Elfaky, M.A.; Abdelhameed, R.F.A.; Elhady, S.S. Large-scale production of bioactive terrein by Aspergillus terreus strain s020 isolated from the Saudi Coast of the Red Sea. Biomolecules 2019, 9, 480. [CrossRef]

64. Lee, Y.H.; Lee, S.J.; Jung, J.E.; Kim, J.S.; Lee, N.H.; Yi, H.K. Terrein reduces age-related inflammation induced by oxidative stress through Nrf2/ERK1/2/HO-1 signalling in aged HDF cells. Cell Biochem. Funct. 2015, 33, 479-486. [CrossRef]

65. [WHO]. WHO Report on Cancer: Setting Priorities, Investing Wisely and Providing Care for All; World Health Organization: Geneva, Switzerland, 2020; Available online: https://www.who.int/publications-detailredirect/who-report-on-cancer-setting-priorities-investing-wisely-and-providing-care-for-all (accessed on 28 August 2020).

66. Ren, F.; Zhu, S.; Wang, B.; Li, L.; Liu, X.; Su, R.; Che, Y. Hypocriols AF heterodimeric botryane ethers from Hypocrea sp., an insect-associated fungus. J. Nat. Prod. 2016, 79, 1848-1856. [CrossRef] [PubMed]

67. Zhang, J.; Liu, S.S.; Yuan, W.Y.; Wei, J.J.; Zhao, Y.X.; Luo, D.Q. Carotane-type sesquiterpenes from cultures of the insect pathogenic fungus Isaria fumosorosea. J. Asian Nat. Prod. Res. 2017, 21, 1-7. [CrossRef]

68. Chen, P.; Qin, H.J.; Li, Y.W.; Ma, G.X.; Yang, J.S.; Wang, Q. Study on chemical constituents of an edible mushroom Volvariella volvacea and their antitumor activity in vitro. Nat. Prod. Res. 2018, 34, 1-6. [CrossRef]

69. Chowdhury, N.S.; Sohrab, M.H.; Rana, M.S.; Hasan, C.M.; Jamshidi, S.; Rahman, K.M. Cytotoxic naphthoquinone and azaanthraquinone derivatives from an endophytic Fusarium solani. J. Nat. Prod. 2017, 80, 1173-1177. [CrossRef] [PubMed]

70. Ory, L.; Nazih, E.H.; Daoud, S.; Mocquard, J.; Bourjot, M.; Margueritte, L.; Delsuc, M.A.; Bard, J.M.; Pouchus, Y.F.; Bertrand, S.; et al. Targeting bioactive compounds in natural extracts-Development of a comprehensive workflow combining chemical and biological data. Anal. Chim. Acta 2019, 1070, $29-42$. [CrossRef] [PubMed]

71. Varga, J.; Baranyi, N.; Chandrasekaran, M.; Vágvölgyi, C.; Kocsubé, S. Mycotoxin producers in the Aspergillus genus: An update. Acta. Biol. Szeged. 2015, 59, 151-167.

72. Abdel-Azeem, A.M.; Abdel-Azeem, M.A.; Darwish, A.G.; Nafady, N.A.; Ibrahim, N.A. Fusarium: Biodiversity, Ecological Significances, and Industrial Applications. In Recent Advancement in White Biotechnology through Fungi, Fungal Biology; Yadav, A.N., Singh, S., Mishra, S., Gupta, A., Eds.; Springer Nature: Cham, Switzerland, 2019; Volume 3, pp. 201-261.

73. Neha, K.; Haider, M.R.; Pathak, A.; Yar, M.S. Medicinal prospects of antioxidants: A review. Eur. J. Med. Chem. 2019, 178, 687-704. [CrossRef]

74. Wolfe, K.L.; Liu, R.H. Cellular antioxidant activity (CAA) assay for assessing antioxidants, foods, and dietary supplements. J. Agric. Food Chem. 2007, 55, 8896-8907. [CrossRef]

75. Granato, D.; Shahidi, F.; Wrolstad, R.; Kilmartin, P.; Melton, L.D.; Hidalgo, F.J.; Miyashita, K.; Camp, J.; Alasalvar, C.; Ismail, A.B.; et al. Antioxidant activity, total phenolics and flavonoids contents: Should we ban in vitro screening methods? Food Chem. 2018, 264, 471-475. [CrossRef]

76. Hameed, A.; Hussain, S.A.; Yang, J.; Ijaz, U.M.; Liu, Q.; Suleria, H.A.R.; Song, Y. Antioxidants potential of the filamentous fungi (Mucor circinelloides). Nutrients 2017, 9, 1101. [CrossRef]

77. Furman, D.; Campisi, J.; Verdin, E.; Carrera-Bastos, P.; Targ, S.; Franceschi, C.; Ferrucci, L.; Gilroy, D.W.; Fasano, A.; Miller, G.W.; et al. Chronic inflammation in the etiology of disease across the life span. Nat. Med. 2019, 25, 1822-1832. [CrossRef]

78. Pan, F.; El-Kashef, D.H.; Kalscheuer, R.; Müller, W.E.G.; Lee, J.; Feldbrügge, M.; Mándi, A.; Kurtán, T.; Liu, Z.; Wu, W.; et al. Cladosins L-O, new hybrid polyketides from the endophytic fungus Cladosporium sphaerospermum WBS017. Eur. J. Med. Chem. 2020, 191, 112159. [CrossRef]

79. Al-Rabia, M.W.; Mohamed, G.A.; Ibrahim, S.R.M.; Asfoura, H.Z. Anti-inflammatory ergosterol derivatives from the endophytic fungus Fusarium chlamydosporum. Nat. Prod. Res. 2020. [CrossRef]

80. Xiao, Y.; Xu, B.; Kang, Y.; Li, Y.; Cui, Y.; Liu, W.; Xiang, Z. A neuroinflammation inhibitor, hypoxylon xanthone A, from soil fungus Hypoxylon sp. Lett. Org. Chem. 2020, 17, 116-120. [CrossRef]

81. Wang, A.; Zhao, S.; Gu, G.; Xu, D.; Zhang, X.; Lai, D.; Zhou, L. Rhizovagine A, an unusual dibenzo-a-pyrone alkaloid from the endophytic fungus Rhizopycnisvagum nitaf 22. RSC Adv. 2020, 10, 27894-27898. [CrossRef] 
82. Chapla, V.M.; Honório, A.E.; Gubiani, J.R.; Vilela, A.F.L.; Young, M.C.M.; Cardoso, C.L.; Pavan, F.R.; Cicarelli, R.M.; Ferreira, P.M.P.; Bolzani, V.S.; et al. Acetylcholinesterase inhibition and antifungal activity of cyclohexanoids from the endophytic fungus Saccharicola sp. Phytochem. Lett. 2020, 39, 116-123. [CrossRef]

83. Qi, J.; Zhao, P.; Zhao, L.; Jia, A.; Liu, C.; Zhang, L.; Xia, X. Anthraquinone derivatives from a sea cucumber-derived Trichoderma sp. fungus with antibacterial activities. Chem. Nat. Compd. 2020, 56, 112-114. [CrossRef]

84. Adpressa, D.A.; Connolly, L.R.; Konkel, Z.M.; Neuhaus, G.F.; Chang, X.L.; Pierce, B.R.; Smith, K.M.; Freitag, M.; Loesgen, S. A metabolomics-guided approach to discover Fusarium graminearum metabolites after removal of a repressive histone modification. Fungal Genet. Biol. 2019, 132, 103256. [CrossRef] [PubMed]

85. Giavasis, I. Bioactive fungal polysaccharides as potential functional ingredients in food and nutraceuticals. Curr. Opin. Biotechnol. 2014, 26, 162-173. [CrossRef] [PubMed]

86. Chuang, M.H.; Chiou, S.H.; Huang, C.H.; Yang, W.B.; Wong, C.H. The lifespan-promoting effect of acetic acid and Rishi polysaccharide. Bioorg. Med. Chem. 2009, 17, 7831-7840. [CrossRef] [PubMed]

87. Wu, T.R.; Lin, C.S.; Chang, C.J.; Lin, T.L.; Martel, J.; Ko, Y.F.; Ojcius, D.M.; Lu, C.C.; Young, J.D.; Lai, H.C. Gut commensal Parabacteroides goldsteinii plays a predominant role in the anti-obesity effects of polysaccharides isolated from Hirsutella sinensis. Gut 2019, 68, 248-262. [CrossRef]

88. Chang, C.J.; Lin, C.S.; Lu, C.C.; Martel, J.; Ko, Y.F.; Ojcius, D.M.; Tseng, S.F.; Wu, T.R.; Chen, Y.Y.M.; Young, J.D.; et al. Ganoderma lucidum reduces obesity in mice by modulating the composition of the gut microbiota. Nat. Commun. 2015, 6, 7489. [CrossRef]

89. Rajtilak, M.; Matt, L.; Brian, M.; Rakesh, M.; Subhash, M.; Carol, C.W.; Christine, S.; Kanniah, R.; Jeffrey, C. The Aspergillus flavus spermidine synthase (spds) gene, is required for normal development, aflatoxin production, and pathogenesis during infection of Maize Kernels. Front. Plant Sci. 2018, 9, 317. [CrossRef]

90. Madeo, F.; Eisenberg, T.; Pietrocola, F.; Kroemer, G. Spermidine in health and disease. Science 2018, 359. [CrossRef] [PubMed]

91. Kiechl, S.; Pechlaner, R.; Willeit, P.; Notdurfter, M.; Paulweber, B.; Willeit, K.; Werner, P.; Ruckenstuhl, C.; Iglseder, B.; Weger, S.; et al. Higher spermidine intake is linked to lower mortality: A prospective population-based study. Am. J. Clin. Nutr. 2018, 108, 371-380. [CrossRef] [PubMed]

92. Kała, K.; Kryczyk-Poprawa, A.; Rzewińska, A.; Muszyńska, B. Fruiting bodies of selected edible mushrooms as a potential source of lovastatin. Eur. Food. Res. Technol. 2020, 246, 713-722. [CrossRef]

93. Dong, Y.; Jing, T.; Meng, Q.; Liu, C.; Hu, S.; Ma, Y.; Liu, Y.; Lu, J.; Cheng, Y.; Wang, D.; et al. Studies on the antidiabetic activities of Cordyceps militaris extract in diet-streptozotocin-induced diabetic Sprague-Dawley rats. Biomed Res. Int. 2014, 2014, 160980. [CrossRef] [PubMed]

94. Wu, L.; Sun, H.; Hao, Y.; Zheng, X.; Song, Q.; Dai, S.; Zhu, Z. Chemical structure and inhibition on $\alpha$-glucosidase of the polysaccharides from Cordyceps militaris with different developmental stages. Int. J. Biol. Macromol. 2020, 148, 722-736. [CrossRef]

95. He, S.; Wang, Y.; Xie, J.; Gao, H.; Li, X.; Huang, Z. 1H NMR-based metabolomic study of the effects of flavonoids on citrinin production by Monascus. Food Res. Int. 2020, 137, 109532. [CrossRef]

96. Guo, L.; Li, K.; Kang, J.S.; Kang, N.J.; Son, B.G.; Choi, Y.W. Strawberry fermentation with Cordyceps militaris has anti-adipogenesis activity. Food Biosci. 2020, 35, 100576. [CrossRef]

97. Ashraf, S.A.; Elkhalifa, A.E.O.; Siddiqui, A.J.; Patel, M.; Awadelkareem, A.M.; Snoussi, M.; Ashraf, M.S.; Adnan, M.; Hadi, S. Cordycepin for health and wellbeing: A potent bioactive metabolite of an entomopathogenic Cordyceps medicinal fungus and its nutraceutical and therapeutic potential. Molecules 2020, 25, 2735. [CrossRef]

98. Guo, P.; Kai, Q.; Gao, J.; Lian, Z.Q.; Wu, C.M.; Wu, C.A.; Zhu, H.B. Cordycepin prevents hyperlipidemia in hamsters fed a high-fat diet via activation of AMP-activated protein kinase. J. Pharmacol. Sci. 2010, 113, 395-403. [CrossRef]

99. Kopalli, S.R.; Cha, K.M.; Lee, S.H.; Hwang, S.Y.; Lee, Y.J.; Koppula, S.; Kim, S.K. Cordycepin, an active constituent of nutrient powerhouse and potential medicinal mushroom Cordyceps militaris Linn., ameliorates age-related testicular dysfunction in rats. Nutrients 2019, 11,906. [CrossRef]

100. Kerrigan, R.W. Agaricus subrufescens, a cultivated edible and medicinal mushroom, and its synonyms. Mycologia 2005, 97, 12-24. [CrossRef] 
101. Taofiq, O.; Rodrigues, F.; Barros, L.; Peralta, R.M.; Barreiro, M.F.; Ferreira, I.C.F.R.; Oliveira, M.B.P.P. Agaricus blazei Murrill from Brazil: An ingredient for nutraceutical and cosmeceutical applications. Food Funct. 2019, 10, 565-572. [CrossRef] [PubMed]

102. Navegantes-Lima, K.C.; Monteiro, V.V.S.; Gaspar, S.L.F.; Oliveira, A.L.B.; de Oliveira, J.P.; Reis, J.F.; Gomes, R.S.; Rodrigues, C.A.; Stutz, H.; Sovrani, V.; et al. Agaricus brasiliensis mushroom protects against sepsis by alleviating oxidative and inflammatory response. Front. Immunol. 2020, 11, 1238. [CrossRef] [PubMed]

103. Kumar, K.J.S.; Vani, M.G.; Chen, C.Y.; Hsiao, W.W.; Li, J.; Lin, Z.X.; Chu, F.H.; Yen, G.C.; Wang, S.Y. A mechanistic and empirical review of antcins, a new class of phytosterols of formosan fungi origin. J. Food Drug Anal. 2020, 28, 38-59. [CrossRef] [PubMed]

104. Zhang, S.; Sugawara, Y.; Chen, S.; Beelman, R.B.; Tsuduki, T.; Tomata, Y.; Matsuyama, S.; Tsuji, I. Mushroom consumption and incident risk of prostate cancer in Japan: A pooled analysis of the Miyagi Cohort Study and the Ohsaki Cohort Study. Int. J. Cancer 2020, 146, 2712-2720. [CrossRef] [PubMed]

105. Torres-Mendoza, D.; Ortega, H.E.; Cubilla-Rios, L. Patents on endophytic fungi related to secondary metabolites and biotransformation applications. J. Fungi 2020, 6, 58. [CrossRef]

106. Da Rocha, W.R.V.; Costa-Silva, T.A.; Agamez-Montalvo, G.S.; Feitosa, V.A.; Machado, S.E.F.; de Souza Lima, G.M.; Pessoa, A.J.; Alves, H.S. Screening and optimizing fermentation production of l-asparaginase by Aspergillus terreus strain S-18 isolated from the Brazilian Caatinga Biome. J. Appl. Microbiol. 2019, 126, 1426-1437. [CrossRef]

107. Clarance, P.; Khusro, A.; Lalitha, J.; Sales, J.; Paul, A. Optimization of camptothecin production and biomass yield from endophytic fungus Fusarium solani strain ATLOY-8. J. Appl. Pharm. Sci. 2019, 9, 35-46. [CrossRef]

108. Mefteh, F.B.; Frikha, F.; Daoud, A.; Bouket, A.C.; Luptakova, L.; Alenezi, F.N.; Al-Anzi, B.S.; Oszako, T.; Gharsallah, N.; Belbahri, L. Response surface methodology optimization of an acidic protease produced by Penicillium bilaiae isolate TDPEF30, a newly recovered endophytic fungus from healthy roots of date palm trees (Phoenix dactylifera L.). Microorganisms 2019, 7, 74. [CrossRef]

109. Atlı, B.; Yamaç, M.; Yıldız, Z.; Şőlener, M. Solid state fermentation optimization of Pleurotus ostreatus for lovastatin production. Pharm. Chem. J. 2019, 53, 858-864. [CrossRef]

110. Ravuri, M.; Shivakumar, S. Optimization of conditions for production of lovastatin, a cholesterol lowering agent, from a novel endophytic producer Meyerozyma guilliermondii. J. Biol. Product. Nat. 2020, 10, 192-203. [CrossRef]

111. Khan, Y.M.; Munir, H.; Anwar, Z. Optimization of process variables for enhanced production of urease by indigenous Aspergillus niger strains through response surface methodology. Biocatal. Agric. Biotechnol. 2019, 20, 101202. [CrossRef]

112. Suwannarach, N.; Kumla, J.; Watanabe, B.; Matsui, K.; Lumyong, S. Characterization of melanin and optimal conditions for pigment production by an endophytic fungus, Spissiomyces endophytica SDBR-CMU319. PLoS ONE 2019, 14, e0222187. [CrossRef]

113. El-Sayed, E.S.R.; Zaki, A.G.; Ahmed, A.S.; Ismaiel, A.A. Production of the anticancer drug taxol by the endophytic fungus Epicoccum nigrum TXB502: Enhanced production by gamma irradiation mutagenesis and immobilization technique. Appl. Microbiol. Biotechnol. 2020, 1-13. [CrossRef] [PubMed]

114. Zaki, A.G.; El-Shatoury, E.H.; Ahmed, A.S.; Al-Hagar, O.E. Production and enhancement of the acetylcholinesterase inhibitor, huperzine A, from an endophytic Alternaria brassicae AGF041. Appl. Microbiol. Biotechnol. 2019, 103, 5867-5878. [CrossRef]

115. Biswas, D.; Nazir, R.; Biswas, P.; Kumar, V.; Nandy, S.; Mukherjee, A.; Mukherjee, A.; Dey, A.; Pandey, D.K. Endophytic sources of diosgenin, a natural steroid with multiple therapeutic values. S. Afr. J. Bot. 2020. [CrossRef]

116. Bouhri, Y.; Askun, T.; Tunca, B.; Deniz, G.; Aksoy, S.A.; Mutlu, M. The orange-red pigment from Penicillium mallochii: Pigment production, optimization, and pigment efficacy against Glioblastoma cell lines. Biocatal. Agric. Biotechnol. 2020, 23, 101451. [CrossRef]

117. Xu, S.; Ren, N.; Liu, J.; Wu, Y.; Yuan, G. Improvement of vincamine production of endophytic fungus through inactivated protoplast fusion. Int. Microbiol. 2020, 1-11. [CrossRef] [PubMed]

118. Akasaka, N.; Kato, S.; Kato, S.; Hidese, R.; Wagu, Y.; Sakoda, H.; Fujiwara, S. Agmatine production by Aspergillus oryzae is elevated by low $\mathrm{pH}$ during solid-state cultivation. Appl. Environ. Microbiol. 2018, 84, e00722-18. [CrossRef] [PubMed] 
119. Barua, S.; Kim, J.Y.; Kim, J.Y.; Kim, J.H.; Lee, J.E. Therapeutic effect of agmatine on neurological disease: Focus on ion channels and receptors. Neurochem. Res. 2019, 44, 735-750. [CrossRef]

120. [ADI] Alzheimer's Disease International. World Alzheimer Report. In Attitudes to Dementia; Alzheimer's Disease International: London, UK, 2019; Available online: https://www.alz.co.uk/research/world-report-2019 (accessed on 29 August 2020).

121. Patel, R. A moldy application of MALDI: MALDI-ToF mass spectrometry for fungal identification. J. Fungi 2019, 5, 4. [CrossRef] [PubMed]

122. Esteki, M.; Shahsavari, Z.; Simal-Gandara, J. Gas Chromatographic fingerprinting coupled to chemometrics for food authentication. Food Rev. Int. 2019, 36. [CrossRef]

123. Li, Z.; Shi, Y.; Zhang, X.; Xu, J.; Wang, H.; Zhao, L.; Wang, Y. Screening immunoactive compounds of Ganoderma lucidum spores by mass spectrometry molecular networking combined with in vivo Zebrafish assays. Front. Pharmacol. 2020, 11, 287. [CrossRef] [PubMed]

124. Markley, J.L.; Brüschweiler, R.; Edison, A.S.; Eghbalnia, H.R.; Powers, R.; Raftery, D.; Wishart, D.S. The future of NMR-based metabolomics. Curr. Opin. Biotech. 2017, 43, 34-40. [CrossRef]

125. Li, S.; Tian, Y.; Jiang, P.; Lin, Y.; Liu, X.; Yang, H. Recent advances in the application of metabolomics for food safety control and food quality analyses. Crit. Rev. Food Sci. Nutr. 2020, 1-22. [CrossRef]

126. Hammerl, R.; Frank, O.; Schmittnägel, T.; Ehrmann, M.A.; Hofmann, T. Functional metabolome analysis of Penicillium roqueforti by means of differential off-line LC-NMR. J. Agric. Food Chem. 2019, 67, 5135-5146. [CrossRef]

127. Alanne, A.L.; Issakainen, J.; Pihlaja, K.; Jokioja, J.; Sinkkonen, J. Metabolomic discrimination of the edible mushrooms Kuehneromyce smutabilis and Hypholom acapnoides (Strophariaceae, Agaricales) by NMR spectroscopy. Z. Naturforsch. 2019, 74, 201-210. [CrossRef]

128. González-Domínguez, R.; Sayago, A.; Fernández-Recamales, A. Metabolomics: An emerging tool for wine characterization and the investigation of health benefits. In Engineering Tools in the Beverage Industry: The Science of Beverages; Grumezescu, A.M., Holban, A.M., Eds.; Wood Head Publishing: Sawston, UK, 2019; Volume 3, pp. 315-350. [CrossRef]

129. Florentino-Ramos, E.; Villa-Ruano, N.; Hidalgo-Martínez, D.; Ramírez-Meraz, M.; Méndez-Aguilar, R.; Velásquez-Valle, R.; Zepeda-Vallejo, L.G.; Pérez-Hernández, N.; Becerra-Martínez, E. ${ }^{1}$ H NMR-based fingerprinting of eleven Mexican Capsicum annuum cultivars. Food Res. Int. 2019, 121, 12-19. [CrossRef]

130. Gasecka, M.; Siwulski, M.; Mleczek, M. Evaluation of bioactive compounds content and antioxidant properties of soil-growing and wood-growing edible mushrooms. J. Food Process. Preserv. 2017, e13386. [CrossRef]

131. Carr, A.C.; Lykkesfeldt, J. Discrepancies in global vitamin C recommendations: A review of RDA criteria and underlying health perspectives. Crit. Rev. Food Sci. Nutr. 2020, 1-14. [CrossRef]

132. Da Silva, L.P.; Vargas, E.A.; Madureira, F.D.; Faria, A.F.; Augusti, R. Development and validation of a novel analytical method to quantify aflatoxins in baby food samples by employing dispersive solid phase extraction with multi-walled carbon nanotubes. Food Anal. Methods 2020, 13, 1530-1537. [CrossRef]

133. Orhan, I.E.; Senol, F.S.; Skalicka-Wozniak, K.; Georgiev, M.; Sener, B. Adulteration and safety issues in nutraceuticals and dietary supplements: Innocent or risky? In Nutraceuticals: Nanotechnology in the Agri-Food Industry; Grumezescu, A.M., Ed.; Academic Press: Cambridge, UK, 2016; Volume 4, pp. 153-182.

134. Colosimo, R.; Gabriele, M.; Cifelli, M.; Longo, V.; Domenici, V.; Pucci, L. The effect of sourdough fermentation on Triticum dicoccum from Garfagnana: ${ }^{1} \mathrm{H}$ NMR characterization and analysis of the antioxidant activity. Food Chem. 2020, 305, 125510. [CrossRef] [PubMed]

135. Papadaki, E.; Mantzouridou, F.T. Citric acid production from the integration of Spanish-style green olive processing wastewaters with white grape pomace by Aspergillus niger. Bioresour. Technol. 2019, 280, 59-69. [CrossRef] [PubMed]

136. Faustino, M.; Veiga, M.; Sousa, P.; Costa, E.M.; Silva, S.; Pintado, M. Agro-food byproducts as a new source of natural food additives. Molecules 2019, 24, 1056. [CrossRef]

137. Roukas, T.; Kotzekidou, P. Pomegranate peel waste: A new substrate for citric acid production by Aspergillus niger in solid-state fermentation under non-aseptic conditions. Environ. Sci. Pollut. Res. 2020, 27, 13105-13113. [CrossRef] 
138. Souza Filho, P.F.; Zamani, A.; Taherzadeh, M.J. Edible protein production by filamentous fungi using starch plant wastewater. Waste Biomass Valoriz. 2019, 10, 2487-2496. [CrossRef]

139. Dulf, F.V.; Vodnar, D.C.; Toşa, M.I.; Dulf, E.H. Simultaneous enrichment of grape pomace with $\gamma$-linolenic acid and carotenoids by solid-state fermentation with Zygomycetes fungi and antioxidant potential of the bioprocessed substrates. Food Chem. 2020, 310, 125927. [CrossRef] [PubMed]

Publisher's Note: MDPI stays neutral with regard to jurisdictional claims in published maps and institutional affiliations.

(C) 2020 by the authors. Licensee MDPI, Basel, Switzerland. This article is an open access article distributed under the terms and conditions of the Creative Commons Attribution (CC BY) license (http://creativecommons.org/licenses/by/4.0/). 